Article

\title{
Response of Vertical Migration and Leaching of Nitrogen in Percolation Water of Paddy Fields under Water-Saving Irrigation and Straw Return Conditions
}

\author{
Chengxin Zheng ${ }^{1,2}$, Zhanyu Zhang ${ }^{2,3, *}$, Yunyu $\mathrm{Wu}^{2,3}$ and Richwell Mwiya ${ }^{1,2}$ \\ 1 College of Water Conservancy and Hydropower Engineering, Hohai University, Nanjing 210098, China; \\ chengxin@hhu.edu.cn (C.Z.); richwellmobi@gmail.com (R.M.) \\ 2 Key Laboratory of Efficient Irrigation-Drainage and Agricultural Soil-Water Environment in Southern China \\ of Ministry of Education, Hohai University, Nanjing 210098, China; 15950508033@163.com \\ 3 College of Agricultural Engineering, Hohai University, Nanjing 210098, China \\ * Correspondence: zhanyu@hhu.edu.cn; Tel.: +86-25-8378-6947
}

Received: 1 April 2019; Accepted: 23 April 2019; Published: 25 April 2019

check for updates

\begin{abstract}
The use of water-saving irrigation techniques has been encouraged in rice fields in response to irrigation water scarcity. Straw return is an important means of straw reuse. However, the environmental impact of this technology, e.g., nitrogen leaching loss, must be further explored. A two-year (2017-2018) experiment was conducted to investigate the vertical migration and leaching of nitrogen in paddy fields under water-saving and straw return conditions. Treatments included traditional flood irrigation (FI) and two water-saving irrigation regimes: rain-catching and controlled irrigation (RC-CI) and drought planting with straw mulching (DP-SM). RC-CI and DP-SM both significantly decreased the irrigation input compared with FI. RC-CI increased the rice yield by $8.23 \% \sim 12.26 \%$, while DP-SM decreased it by $8.98 \% \sim 15.24 \%$ compared with FI. NH${ }_{4}^{+}-\mathrm{N}$ was the main form of the nitrogen leaching loss in percolation water, occupying $49.06 \% \sim 50.97 \%$ of TN leaching losses. The $\mathrm{NH}_{4}{ }^{+}-\mathrm{N}$ and TN concentration showed a decreasing trend from top to bottom in soil water of $0 \sim 54 \mathrm{~cm}$ depth, while the concentration of $\mathrm{NO}_{3}{ }^{-}-\mathrm{N}$ presented the opposite behavior. The TN and $\mathrm{NH}_{4}{ }^{+}-\mathrm{N}$ concentrations in percolation water of RC-CI during most of the rice growth stage were the highest among treatments in both years, and DP-SM showed a trend of decreasing TN and $\mathrm{NH}_{4}{ }^{+}-\mathrm{N}$ concentrations. The $\mathrm{NO}_{3}{ }^{-}-\mathrm{N}$ concentrations in percolation water showed a regular pattern of DP-SM > RC-CI > FI during most of the rice growth stage. RC-CI and DP-SM remarkably reduced the amount of $\mathrm{N}$ leaching losses compared to FI as a result of the significant decrease of percolation water volumes. The tillering and jointing-booting stages were the two critical periods of $\mathrm{N}$ leaching (accounted for $74.85 \% \sim 86.26 \%$ of $\mathrm{N}$ leaching losses). Great promotion potential of RC-CI and DP-SM exists in the lower reaches of the Yangtze River, China, and DP-SM needs to be further optimized.
\end{abstract}

Keywords: rice; water-saving irrigation; straw; nitrogen; vertical migration; leach

\section{Introduction}

Water plays a critical role in stable agricultural production, especially for paddy rice, which has greater water requirements [1,2]. Rice is one of the most important food crops in China. The rice production of China ranks first in the world, occupying $28 \%$ of the world's total rice production [3]. With climate change and the increasing competition for water from non-agricultural sectors, such as urbanization, tourism industry and ecosystem services, it is essential to reduce the use of irrigation 
water in agricultural production $[4,5]$. Several water-saving irrigation technologies based on alternate wetting and drying (AWD), such as saturated soil culture, controlled irrigation, intermittent irrigation, aerobic rice, controlled irrigation and drainage, have been developed for rice production in China [6-11]. However, the environmental effects of these water-saving irrigation technologies are not well understood.

Agricultural non-point source pollution is one of the main sources of pollution for water eutrophication and ground water pollution. As a result of excess use of chemicals and fertilizers, massive quantities of nutrients are removed from soil, passing into surface and ground waters in farmlands. The variation of water in rice fields is more frequent than that in dry land, with more leakage and runoff events. Though water-saving irrigation can considerably reduce water input in paddy fields, a risk exists of increasing percolation of water and solute through cracks caused by soil desiccation when the field changes from dry to wet [12-14]. Nitrogen (N) plays an essential role in crop yield formation due to its fundamental role in biomass accumulation $[15,16]$. However, excess $\mathrm{N}$ fertilizer application can cause heavy $\mathrm{N}$ loss, leading to severe negative environmental impacts, for example, the pollution of groundwater and surface water, soil pollution and emissions of greenhouse gases [17-20]. The application rate of $\mathrm{N}$ fertilizer in rice paddy fields was up to $324 \mathrm{~kg} / \mathrm{ha}$ in the Yangtze River region, where more than $60 \%$ of rice in China is produced [16,21]. Previous studies found that only $30 \sim 40 \%$ of the applied $\mathrm{N}$ fertilizer was absorbed and utilized by rice plants, while more than $45 \%$ was lost to the surrounding environment [16,22-24].

As one of the major measures for rice field management, irrigation greatly influences the migration of nutrients from the field. Different from flood irrigation, AWD changed the distribution and loss characteristics of nitrogen in soil and influenced the nitrogen uptake by rice plants [25]. The dry and wet circulation of paddy soil under AWD could dramatically change the soil physical environment. The cyclical change between aerobic and anaerobic is completely different from that of traditional flood irrigation, which in turn changes microbial processes such as mineralization, nitrification, and denitrification. Nitrogen leaching losses become more uncertain and obscure due to the interactions between water volume and nitrogen concentrations of percolation water [12]. Some studies reported that AWD can lead to greater nutrient leaching than FI [26,27]. In contrast, several studies reported that water-saving irrigation reduced $\mathrm{N}$ leaching losses from paddy fields [12,28,29]. Peng et al. [29] reported that significant reductions in nitrogen leaching losses of water-saving irrigation were achieved by both the decreasing total percolation water volume and $\mathrm{N}$ concentrations in percolation water. However, Tan et al. [12] reported that water-saving irrigation increased the $\mathrm{N}$ concentrations in percolation water, and that the reduction in nitrogen leaching losses of water-saving irrigation was mainly due to the decreasing total percolation water volume. Furthermore, the forms of nitrogen such as $\mathrm{NO}_{3}{ }^{-}-\mathrm{N}$ and $\mathrm{NH}_{4}{ }^{+}-\mathrm{N}$ losses through leaching are entirely inconsistent among limited studies [12,29]. Some studies found that $\mathrm{NH}_{4}{ }^{+}-\mathrm{N}$ was the major form of $\mathrm{N}$ losses in percolation water under controlled irrigation [29,30]. However, Ji et al. [31] reported that $\mathrm{NH}_{4}{ }^{+}-\mathrm{N}$ and $\mathrm{NO}_{3}{ }^{-}-\mathrm{N}$ took up 39.7\% and 3.5\% of the TN leaching losses in Dongting Lake area of China, which was consistent with the result of Zhao et al. [32] in the Taihu region of China, indicating that $\mathrm{NO}_{3}{ }^{-}-\mathrm{N}$ was the main form of $\mathrm{N}$ in the percolation water in paddy fields. The contrasting results may be due to the differences in frequency and the threshold of the drying cycles, soil types and textures, soil-hydrological conditions, rice growth situations and the environment.

Straw return is an important organic agriculture management practice, which may increase soil carbon sequestration and decrease chemical inputs without influencing crop yields [33,34]. Appropriate straw return to agricultural soil might be an effective way of controlling $\mathrm{N}$ leaching $[35,36]$. Jiangsu Province is a typical area of rice cultivation in the lower reaches of the Yangtze River. Rain-catching and controlled irrigation (RC-CI) [37], also called controlled irrigation and drainage $[10,30]$, is a widely-used water-saving irrigation that increases water storage depth after rainfall based on controlled irrigation (CI) in Jiangsu Province. Drought planting with straw mulching (DP-SM), a water-saving irrigation regime of aerobic rice with straw return, hasn't been well tested 
and popularized in Jiangsu. The field conditions change with changes in irrigation methods or soil conditions. Thus, it is necessary to investigate the effect of different water-saving irrigation regimes and straw return on nitrogen migration and leaching losses in the lower reaches of the Yangtze River.

The objective of this study was to investigate the water use, vertical migration and leaching of nitrogen in paddy fields under water-saving and straw return conditions during the whole rice growth season in the lower reaches of the Yangtze River of China. Treatments included traditional flooding irrigation (FI, as CK) and two water-saving irrigation regimes: RC-CI and DP-SM. Different thresholds of water-saving irrigation were set in different rice growth stages, instead of a fixed value during the whole rice growing season. The study is of great significance for assessing and analyzing the risk of nitrogen leaching in paddy fields in the region and rational use of water-saving irrigation methods to achieve good environmental benefits, promoting sustainable agricultural development.

\section{Materials and Methods}

\subsection{Description of Study Area and Climatic Conditions}

The study was conducted in specially designed experimental buckets at the Key Laboratory of Efficient Irrigation-Drainage and Agricultural Soil-Water Environment in Southern China, Ministry of Education (latitude $31^{\circ} 57^{\prime} \mathrm{N}$, longitude $118^{\circ} 50^{\prime} \mathrm{E}$, and $144 \mathrm{~m}$ above sea level) during the rice growing seasons of 2017 and 2018. The study area has a subtropical humid monsoon climate with an average annual temperature of $15.7^{\circ} \mathrm{C}$, annual precipitation of $1021.3 \mathrm{~mm}$, annual evaporation of $900 \mathrm{~mm}$, annual average sunshine of $2212.8 \mathrm{~h}$, and a frost free period of 220 days per year. The soil texture of the experimental site in the plowed layer is loamy clay, with organic matter of $2.40 \%$, total nitrogen of $0.9 \mathrm{~g} / \mathrm{kg}$, available nitrogen of $47.4 \mathrm{mg} / \mathrm{kg}$, total phosphorus of $33.0 \mathrm{mg} / \mathrm{kg}$, available phosphorus of $10.4 \mathrm{mg} / \mathrm{kg}$ and $\mathrm{pH}$ of 8.0 . The saturated water content of the soil is $38.2 \%$ by mass and the soil water wilting point is $6.9 \%$. The soil bulk density is $1.31 \mathrm{~g} / \mathrm{cm}^{3}$.

\subsection{Experimental Design}

The experiment was laid out in a Randomized Complete Block Design, consisting of three treatments with five replications. All treatments were applied to the same buckets for both years of the study. Designed buckets (Figure 1) were used for rice cultivation. The soil was scraped, starting from the plowed layer in the experimental site. After scraping with a layer of about every $10 \mathrm{~cm}$ from top to bottom, the soil was air-dried and then layered and compacted according to the bulk density. The soil $(0 \sim 60 \mathrm{~cm}$ depth) in the experiment buckets was expected to be representative of the field soil in the experimental region.

Treatments included FI (as CK) and two water-saving irrigation regimes: RC-CI and DP-SM. Under water-saving irrigation regimes, the paddy field was kept in alternate wetting and drying conditions, with many periods without water depth, instead of maintaining flood conditions throughout the whole rice growth season. Different thresholds were set in different rice growth stages under the two water-saving irrigation regimes instead of a fixed value during the whole rice growing season. RC-CI technology was set as a water-saving irrigation regime that maintained different rainwater storage levels in different rice growth stages after rainfall, raising higher water depths after rainfall than that of controlled irrigation. The DP-SM treatment was covered with two $\mathrm{cm}$ thick semi-decomposed straw over the surface of the soil. The straw was cut into pieces of five $\mathrm{cm}$ in length and the covered straw converted into dry matter weight was $6000 \mathrm{~kg} / \mathrm{ha}$. Different controlled thresholds in different rice growth stages among treatments are presented in Table 1. All treatments were exposed to natural conditions. 


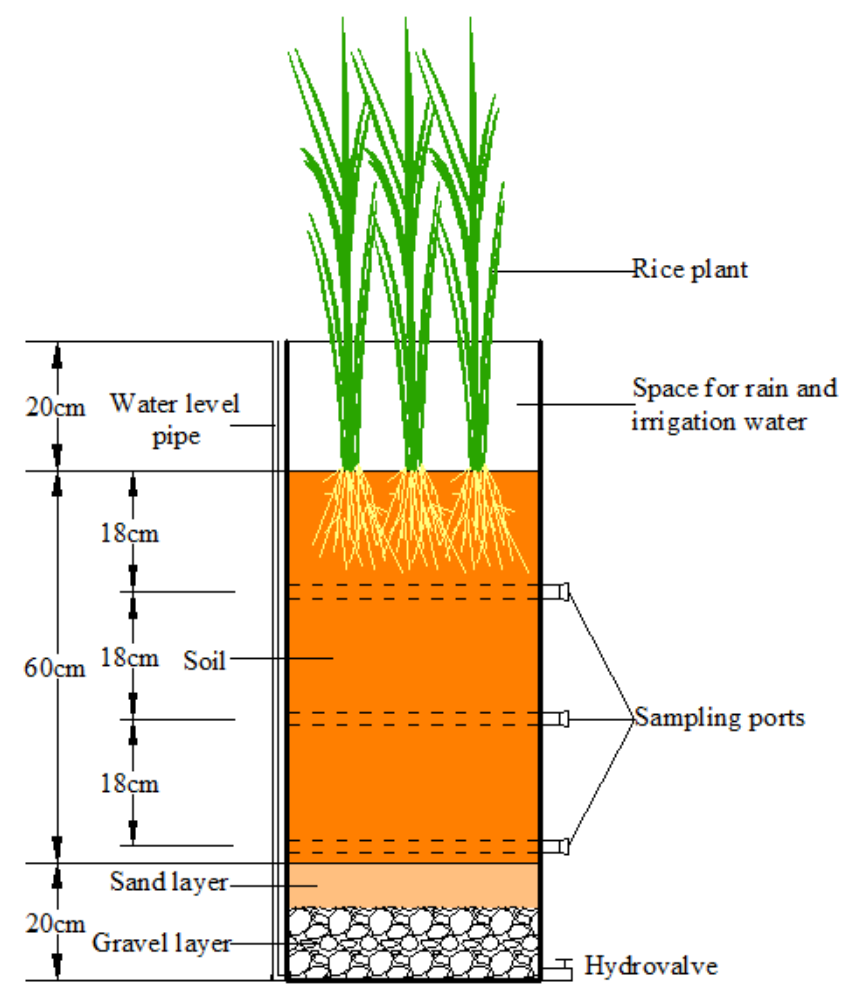

Figure 1. Sketch of the designed experimental bucket.

When the lower bound of irrigation was reached, the rice was irrigated until the water level reached the upper bound of irrigation. When the water level exceeded the rainfall storage upper limited, the excess surface water was drained. Percolation water volume in the field was achieved by controlling the hydrovalve at the bottom of the buckets, referring to the daily average leakage of the studies in nearby areas $[29,30,38]$.

Two super rice varieties widely used in local production, Oryza sativa L. Nanjing 5055 and Oryza sativa L. Nanjing 9108, were grown in the buckets in 2017 and 2018, respectively. Seedlings were raised in a seedbed and sowing dates were 11 May in 2017 and 20 May in 2018. Seedlings were transplanted at six hills per bucket with two seedlings per hill on 17 June in 2017 and four hills per bucket with three seedlings per hill 22 June in 2018. Plants were harvested on 27 October in 2017 and 21 October in 2018. The yield was converted from yield per plant to yield per hectare by local field cultivation. The same fertilizers were applied to all treatments. Local high-yield fertilization method was adopted in this experiment on 2017 and 2018 (Table 2). The buckets were regularly hand-weeded and pesticides were used to prevent insect and pest damage. 
Table 1. Controlled thresholds in different stages for different irrigation regimes.

\begin{tabular}{|c|c|c|c|c|c|c|c|}
\hline \multicolumn{2}{|c|}{ Items } & \multirow{3}{*}{$\begin{array}{c}\text { Re-Greening Stage } \\
1 \sim 9 \\
1 \sim 7\end{array}$} & \multirow{3}{*}{$\begin{array}{c}\text { Tillering Stage } \\
10 \sim 39 \\
8 \sim 41\end{array}$} & \multirow{3}{*}{$\begin{array}{c}\text { Jointing-Booting Stage } \\
40 \sim 64 \\
42 \sim 63\end{array}$} & \multirow{3}{*}{$\begin{array}{c}\text { Heading-Flowering Stage } \\
65 \sim 83 \\
64 \sim 87\end{array}$} & \multirow{3}{*}{$\begin{array}{c}\text { Milky Stage } \\
84 \sim 103 \\
88 \sim 107\end{array}$} & \multirow{3}{*}{$\begin{array}{c}\text { Ripening Stage } \\
104 \sim 122 \\
108 \sim 127\end{array}$} \\
\hline & 2017 & & & & & & \\
\hline Growth Stage Division & 2018 & & & & & & \\
\hline \multirow{3}{*}{ FI } & \multirow{3}{*}{$\begin{array}{l}\text { Irrigation lower limited } \\
\text { Irrigation upper limited } \\
\text { Rainfall storage upper } \\
\text { limited }\end{array}$} & 10 & 10 & 10 & 10 & 10 & \multirow{3}{*}{ Naturally dried } \\
\hline & & 30 & 30 & 40 & 40 & 40 & \\
\hline & & 40 & 100 & 150 & 200 & 200 & \\
\hline \multirow{3}{*}{ RC-CI } & \multirow{3}{*}{$\begin{array}{l}\text { Irrigation lower limited } \\
\text { Irrigation upper limited } \\
\text { Rainfall storage upper } \\
\text { limited }\end{array}$} & 10 & $70 \% \theta s$ & $70 \% \theta \mathrm{s}$ & $80 \% \theta \mathrm{s}$ & $70 \% \theta \mathrm{s}$ & \multirow{3}{*}{ Naturally dried } \\
\hline & & 30 & $100 \% \theta \mathrm{s}$ & $100 \% \theta$ s & $100 \% \theta$ s & $100 \% \theta \mathrm{s}$ & \\
\hline & & 80 & 150 & 200 & 200 & 200 & \\
\hline \multirow{3}{*}{ DP-SM } & Irrigation lower limited & $80 \% \theta \mathrm{s}$ & $60 \% \theta \mathrm{s}$ & $60 \% \theta \mathrm{s}$ & $60 \% \theta \mathrm{s}$ & $50 \% \theta \mathrm{s}$ & \multirow{3}{*}{ Naturally dried } \\
\hline & Irrigation upper limited & $100 \% \theta \mathrm{s}$ & $100 \% \theta \mathrm{s}$ & $100 \% \theta \mathrm{s}$ & $100 \% \theta \mathrm{s}$ & $100 \% \theta \mathrm{s}$ & \\
\hline & $\begin{array}{l}\text { Rainfall storage upper } \\
\text { limited }\end{array}$ & 40 & 60 & 80 & 80 & 80 & \\
\hline
\end{tabular}

Note: The data of growth stage division means the days after transplanting. The data of controlled thresholds with \% means the percentage of the saturated water content ( $\theta$ s) for the $0 \sim 30 \mathrm{~cm}$ soil layers. The data of controlled thresholds without \% means the water depths $(\mathrm{mm})$. There was a field sunning about five days in late tillering stage to restrain nonproductive tillering. 
Table 2. Fertilizer application in 2017 and 2018.

\begin{tabular}{|c|c|c|c|c|}
\hline \multirow{2}{*}{ Fertilizer Application } & \multirow{2}{*}{ Type } & \multirow{2}{*}{ Amount (kg/ha) } & \multicolumn{2}{|c|}{ Date } \\
\hline & & & 2017 & 2018 \\
\hline Base fertilizer & $\begin{array}{c}\mathrm{CO}\left(\mathrm{NH}_{2}\right)_{2} \\
\mathrm{P}_{2} \mathrm{O}_{5} \\
\mathrm{~K}_{2} \mathrm{O}\end{array}$ & $\begin{array}{l}209 \\
110 \\
117\end{array}$ & 17 Jun. & 21 Jun. \\
\hline Tillering fertilizer & $\begin{array}{c}\mathrm{CO}\left(\mathrm{NH}_{2}\right)_{2} \\
\mathrm{~K}_{2} \mathrm{O}\end{array}$ & $\begin{array}{c}105 \\
78\end{array}$ & 27 Jun. & 28 Jun. \\
\hline Panicle fertilizer & $\mathrm{CO}\left(\mathrm{NH}_{2}\right)_{2}$ & 209 & 16 Aug. & 10 Aug. \\
\hline
\end{tabular}

\subsection{Field Measurement and Sampling}

Daily meteorological data were collected using an automatic weather station in the experimental site. The temperature and precipitation during the rice growth season in 2017 and 2018 are shown in Figure 2. Time domain reflectometer (Soil Moisture Equipment, Ltd., Corp., Goleta, CA, USA) and vertical rulers were used to monitor soil moisture and water depths, respectively. The ground water depth was measured by the water level pipe installed according to the connector principle (Figure 1). Irrigation water volumes were measured using digital water meters installed on the pipes. Measuring bottles were used to measure the percolation water volume.

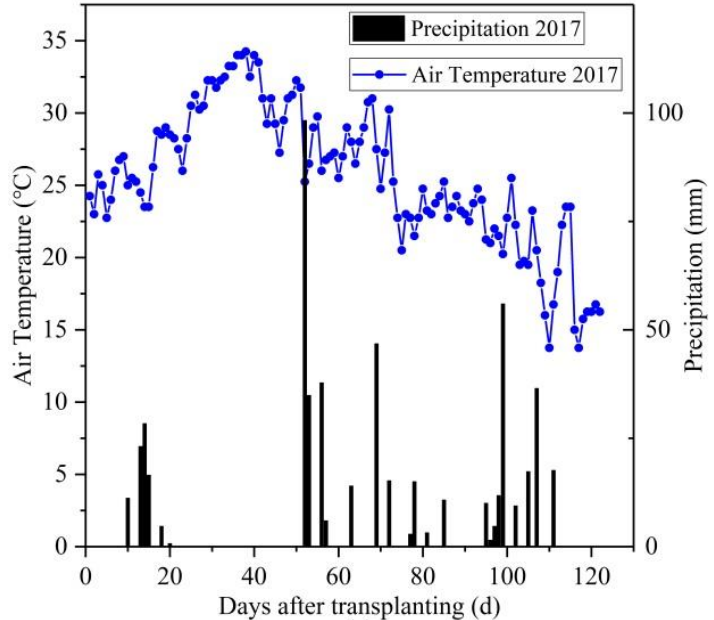

(a)

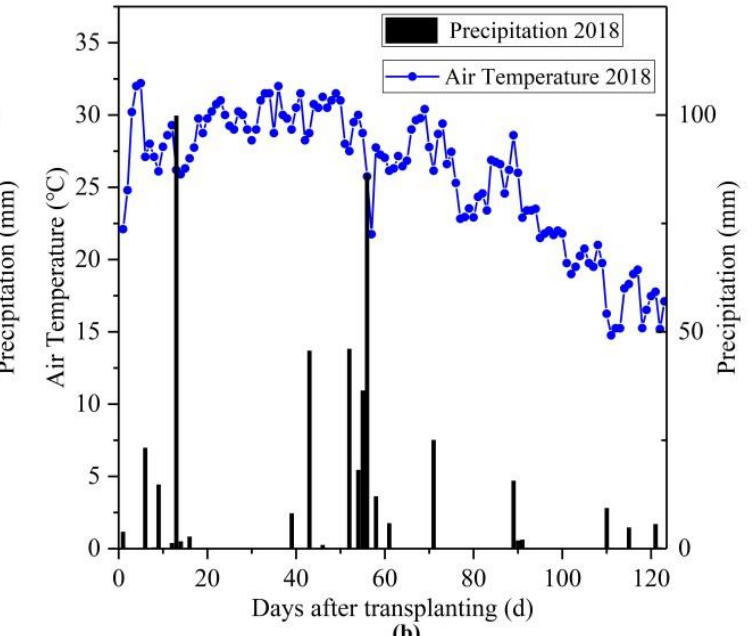

(b)

Figure 2. Daily average temperature and precipitation during the rice growth season in (a) 2017 and (b) 2018.

The percolation water samples were collected through the hydrovalve at the bottom of the buckets. Soil water at $18 \mathrm{~cm}, 36 \mathrm{~cm}$, and $54 \mathrm{~cm}$ depths was obtained from three vertically distributed sampling ports (Figure 1). The water samples were collected into polythene plastic bottles and were stored at $4{ }^{\circ} \mathrm{C}$ before analysis. All polythene plastic bottles were rinsed before an appropriate amount of water was obtained for sampling; the water samples were analyzed within $24 \mathrm{~h}$ thereafter. The percolation water samples were collected at intervals of $3 \sim 6$ days and added to the number of sampling before and after each fertilization. The soil water samples of $18 \mathrm{~cm}, 36 \mathrm{~cm}$, and $54 \mathrm{~cm}$ depth were collected after heavy rainfall or irrigation during the tillering, jointing-booting, heading-flowering and milky stages.

\subsection{Chemical and Statistical Analysis}

The concentrations of $\mathrm{NH}_{4}{ }^{+}-\mathrm{N}, \mathrm{NO}_{3}{ }^{-}-\mathrm{N}$ and $\mathrm{TN}$ were analyzed in a chemical analysis laboratory. The $\mathrm{NH}_{4}{ }^{+}-\mathrm{N}, \mathrm{NO}_{3}{ }^{-}-\mathrm{N}, \mathrm{TN}$ concentrations were determined using the Nessler's reagent colorimetric method, the Ultraviolet spectrophotometry method, the Alkaline potassium persiflage digestion-UV spectrophotometric method using a spectrophotometer (UV-2800, UNICO, Princeton, NJ., USA) for colorimetric, respectively. 
Data were analyzed by one-way ANOVA with least significant difference (LSD) test at the 0.05 probability level. The data for each treatment was the average of five replicates. All statistical analyses were performed using standard procedures for a randomized plot design (SPSS 22.0, SPSS Inc., Chicago, IL, USA).

\section{Results and Discussion}

\subsection{Water Condition and Rice Yield}

The variation of water depths in the field of FI, RC-CI and DP-SM during the rice growth season was extremely different (Figure 3). For the FI treatment, the water depth was maintained throughout almost the whole rice growth stage in both years, except for the period of field sunning in the late tillering stage and the period of ripening stage. However, water depth was maintained only in re-green stage to early tillering stage and after several heavy rains for the RC-CI and DP-SM treatments. About two-thirds of the total rice growth season was in non-flooding conditions under RC-CI treatment in both years and about three-fourths of the total rice growth season was in non-flooding condition under DP-SM treatment.

Total rainfall during the rice growth season was $534.25 \mathrm{~mm}$ in 2017 and $470.70 \mathrm{~mm}$ in 2018 (Table 3). The RC-CI treatment and DP-SM treatment decreased the irrigation volume by $29.14 \%$ and $47.81 \%$ compared to FI in 2017, respectively. In 2018, the irrigation volume of RC-CI and DP-SM decreased by $17.00 \%, 38.84 \%$, respectively. In 2017 and 2018, the percolation water volume of RC-CI was $30.33 \% \sim 41.89 \%$ of that of FI and the percentage was $55.22 \% \sim 69.87 \%$ for DP-SM. RC-CI increased the rice yield by $8.23 \%$ and $12.26 \%$ compared with FI in 2017 and 2018, respectively. And RC-CI increased the irrigation water productivity by $35.26 \% \sim 52.76 \%$ in the two years. However, DP-SM decreased the rice yield by $15.24 \%$ in 2017 and $8.98 \%$ in 2018 compared with FI. DP-SM maintained the highest irrigation water productivity $\left(1.87 \mathrm{~kg} / \mathrm{m}^{3}\right.$ in 2017 and $1.84 \mathrm{~kg} / \mathrm{m}^{3}$ in 2018) in both years, despite the reduction in rice yield. Irrigation water productivity was calculated as grain yield divided by total amount of irrigated water supplied. The increase of rice grain yields and reduction of irrigation water are both likely to increase the irrigation water productivity. Compared with FI, the reduction ratio of irrigation water volume of DP-SM treatment was $38.84 \% \sim 47.81 \%$, much higher than the reduction ratio of rice grain yield $(8.98 \% \sim 15.24 \%)$. As a result, the DP-SM has the highest irrigation water productivity, inducting the best use of water resources in a context of water scarce conditions. Some researchers found that appropriate degree of AWD obtained similar or increased grain yields by 9 18\% compared to FI [37,39-41]. However, the inappropriate control of dryness under AWD could cause reductions in rice yields $[13,37,39]$. The performance in rice yield in our experimental results showed good agreement with the results above. 


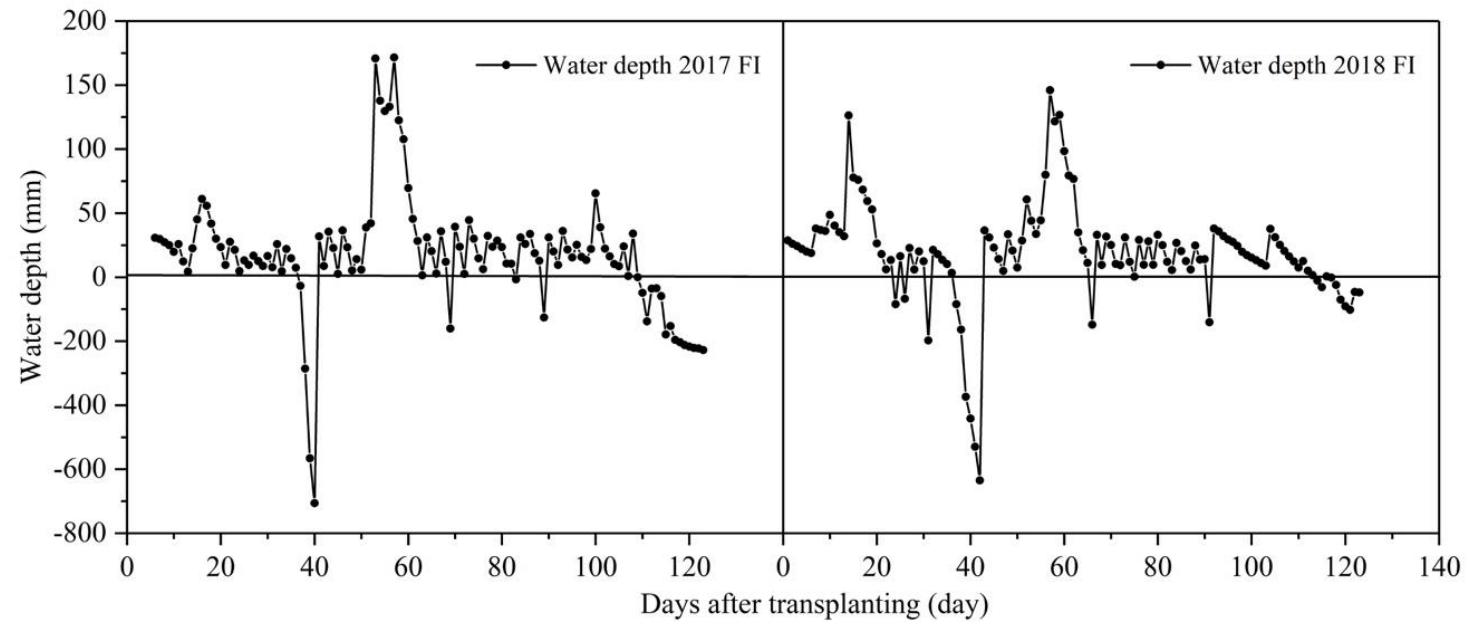

(a)

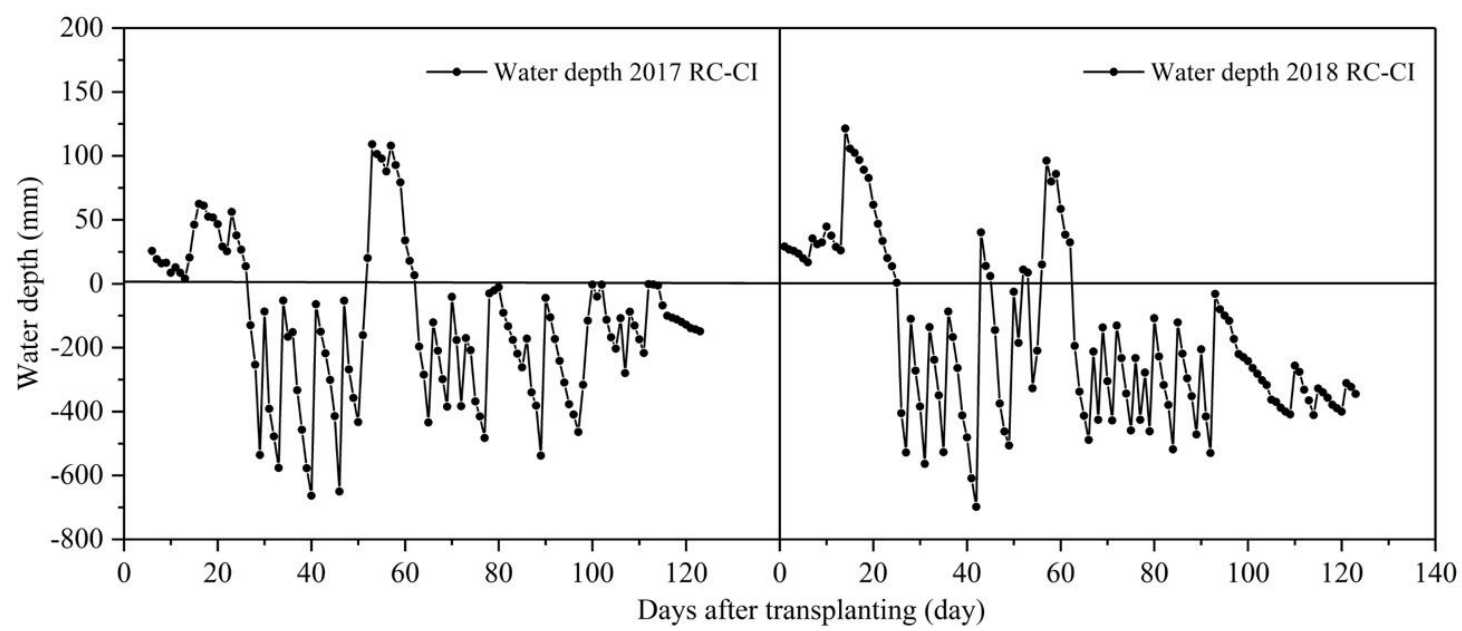

(b)

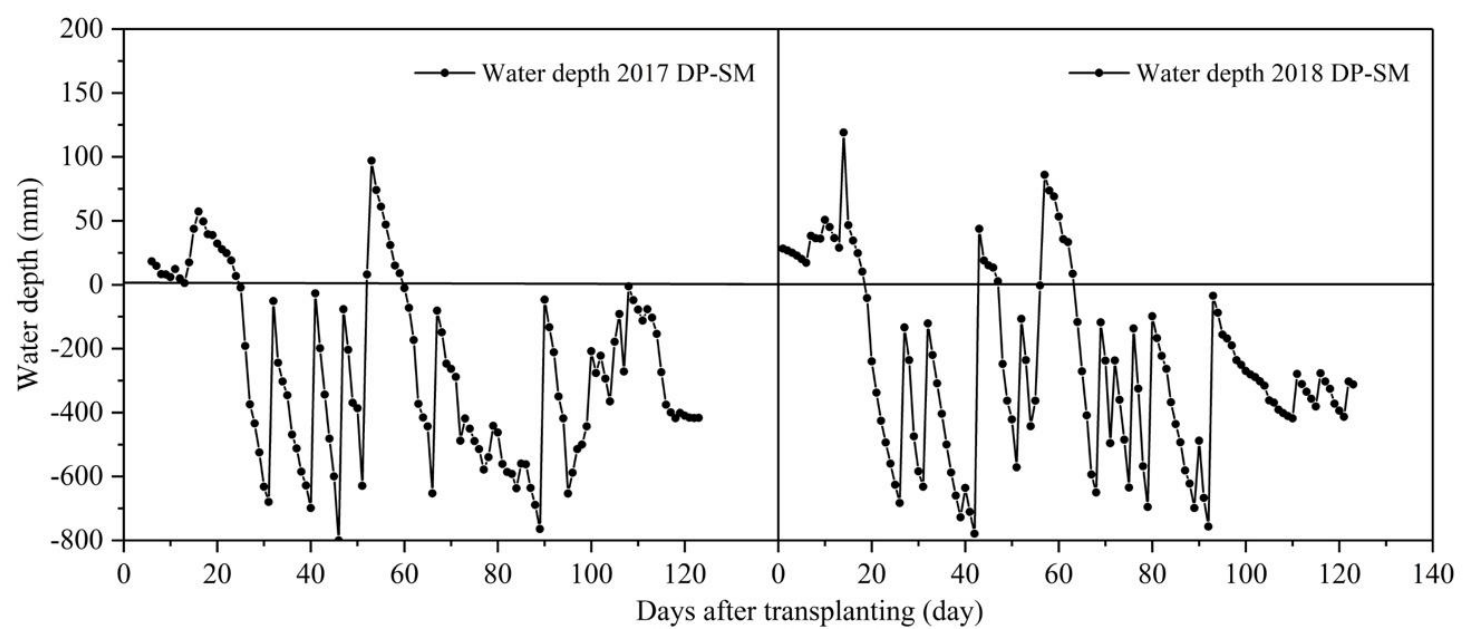

(c)

Figure 3. Water depths of FI (a), RC-CI (b) and DP-SM (c) during the rice growth season in 2017 and 2018. 
Table 3. Irrigation, percolation and rice yield of 2017 and 2018.

\begin{tabular}{ccccccc}
\hline Year & Treatments & Total Irrigation (mm) & Precipitation (mm) & Percolation (mm) & Grain Yield (kg/ha) & $\begin{array}{c}\text { Irrigation Water } \\
\left.\text { Productivity (kg/m } \mathbf{m}^{\mathbf{3}}\right)\end{array}$ \\
\hline \multirow{2}{*}{2017} & FI & $782.88 \mathrm{a}$ & & $364.34 \mathrm{a}$ & $9017.68 \mathrm{~b}$ & $1.15 \mathrm{~b}$ \\
& RC-CI & $554.71 \mathrm{~b}$ & 534.25 & $211.70 \mathrm{~b}$ & $9760.29 \mathrm{a}$ & $1.76 \mathrm{a}$ \\
& DP-SM & $408.59 \mathrm{c}$ & & $109.76 \mathrm{c}$ & $7643.84 \mathrm{c}$ & $1.87 \mathrm{a}$ \\
\hline \multirow{2}{*}{2018} & FI & $826.6 \mathrm{a}$ & & $279.92 \mathrm{a}$ & $10195.74 \mathrm{~b}$ & $1.23 \mathrm{c}$ \\
& RC-CI & $686.05 \mathrm{~b}$ & 470.70 & $195.01 \mathrm{~b}$ & $11446.11 \mathrm{a}$ & $1.67 \mathrm{~b}$ \\
& DP-SM & $505.54 \mathrm{c}$ & & $125.35 \mathrm{c}$ & $9280.30 \mathrm{c}$ & $1.84 \mathrm{a}$ \\
\hline
\end{tabular}

Note: Different letters $(a, b, c)$ in each column of the same year represent significant differences among the treatments $(p<0.05)$.

\subsection{Vertical Migration of $\mathrm{NH}_{4}{ }^{+}-\mathrm{N}, \mathrm{NO}_{3}{ }^{-}-\mathrm{N}$ and $\mathrm{TN}$}

\subsubsection{Vertical Migration of $\mathrm{NH}_{4}{ }^{+}-\mathrm{N}$}

Figure 4 shows the changes of average $\mathrm{NH}_{4}{ }^{+}-\mathrm{N}$ concentrations of different growth stages and the whole growth season in soil water at the depth of 18, 36 and $54 \mathrm{~cm}$ in 2017 and 2018. The average $\mathrm{NH}_{4}{ }^{+}-\mathrm{N}$ concentration during each growth stage (except for the milky stage of 2018), as well as the average concentration during the whole growth season, showed a decreasing trend from top to bottom in 2017 and 2018. Ammonium ions are easily adsorbed by soil and the soil has a retarding effect on the migration of $\mathrm{NH}_{4}{ }^{+}-\mathrm{N}$ [29], which may contribute to the high $\mathrm{NH}_{4}{ }^{+}-\mathrm{N}$ concentration in soil water of the upper soil layer. And the $\mathrm{NH}_{4}{ }^{+}-\mathrm{N}$ concentration in all depths of soil also showed a decreasing trend with the rice growth process and maintained much higher values in tillering stage and jointing-booting stage than the other following rice growth stages in both 2017 and 2018. The absorption and various $\mathrm{N}$ losses with the rice growth may be the main cause for the decrease $[39,42]$.

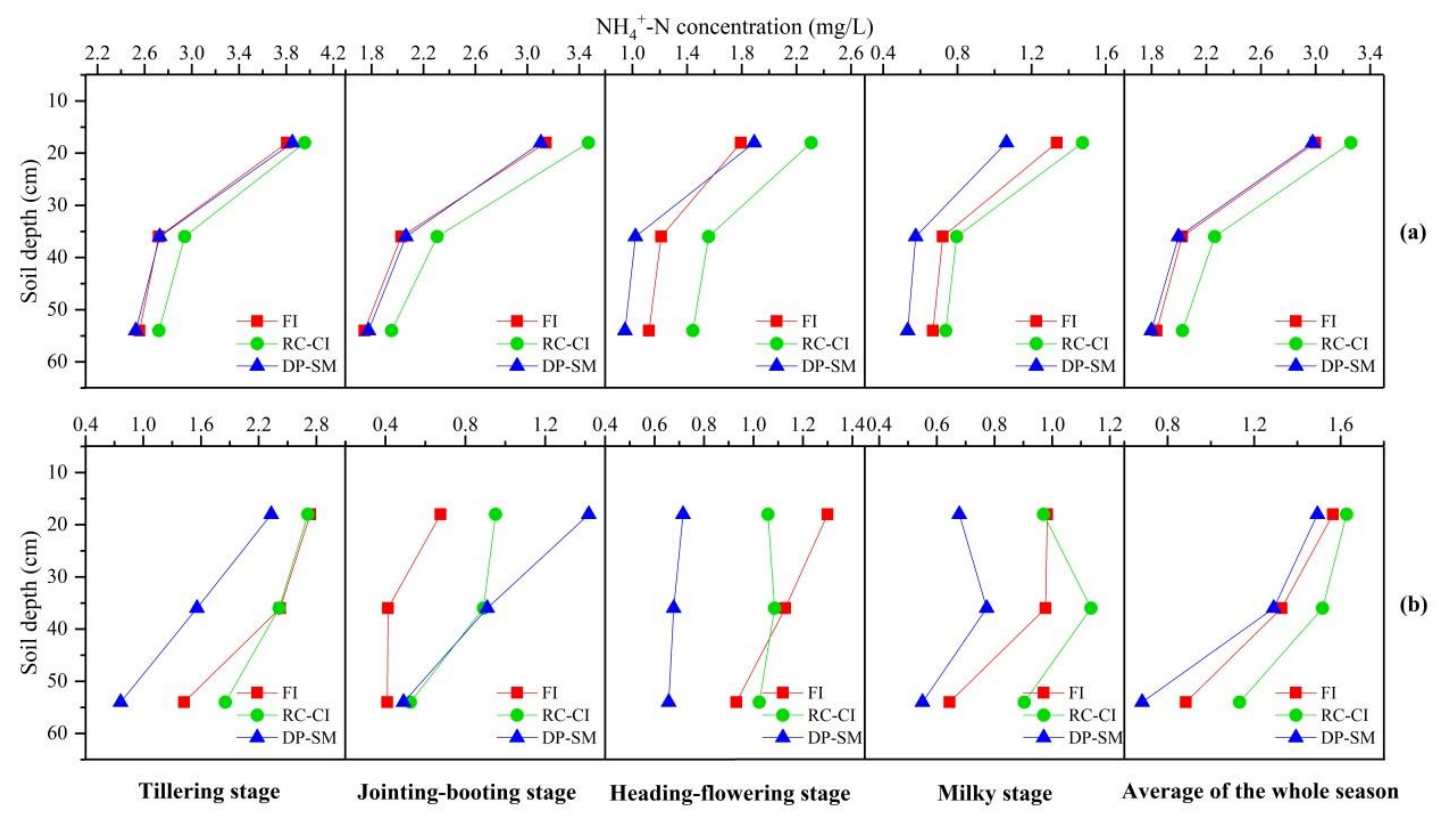

Figure 4. Vertical change of $\mathrm{NH}_{4}{ }^{+}-\mathrm{N}$ concentration in soil water at the depth of 18,36 and $54 \mathrm{~cm}$ in (a) 2017 and (b) 2018 .

In 2017, the average $\mathrm{NH}_{4}{ }^{+}-\mathrm{N}$ concentrations during the whole rice growth season of the $0 \sim 18 \mathrm{~cm}$ depth soil water were $3.00 \mathrm{mg} / \mathrm{L}$ for FI, $3.26 \mathrm{mg} / \mathrm{L}$ for RC-CI, $2.98 \mathrm{mg} / \mathrm{L}$ for DP-SM, respectively. The $\mathrm{NH}_{4}{ }^{+}-\mathrm{N}$ concentration in soil water of $18 \sim 36 \mathrm{~cm}$ depth decreased by $32.52 \%$ for FI, $30.60 \%$ for RC-CI, 32.95\% for DP-SM compared to that of $0 \sim 18 \mathrm{~cm}$ depth, respectively. Then, the $\mathrm{NH}_{4}{ }^{+}-\mathrm{N}$ concentration in soil water of 36 54 cm depth decreased by $9.17 \%$ for $\mathrm{FI}, 10.40 \%$ for RC-CI, $9.95 \%$ for DP-SM compared to that of $18 \sim 36 \mathrm{~cm}$ depth, respectively. The $\mathrm{NH}_{4}{ }^{+}-\mathrm{N}$ concentration decreasing extent of $0 \sim 18 \mathrm{~cm}$ depth to $18 \sim 36 \mathrm{~cm}$ depth was significantly higher than that of $18 \sim 36 \mathrm{~cm}$ depth 
to $36 \sim 54 \mathrm{~cm}$ depth. From $0 \sim 18 \mathrm{~cm}$ depth to $18 \sim 36 \mathrm{~cm}$ depth and then to $36 \sim 54 \mathrm{~cm}$ depth in 2018 , the $\mathrm{NH}_{4}{ }^{+}-\mathrm{N}$ concentration decreased from $1.57 \mathrm{mg} / \mathrm{L}$ to $1.33 \mathrm{mg} / \mathrm{L}$ for FI, $1.63 \mathrm{mg} / \mathrm{L}$ to $1.52 \mathrm{mg} / \mathrm{L}$ for RC-CI, $1.49 \mathrm{mg} / \mathrm{L}$ to $1.29 \mathrm{mg} / \mathrm{L}$ for DP-SM and then sharply decreased to $0.89 \mathrm{mg} / \mathrm{L}, 1.13 \mathrm{mg} / \mathrm{L}$, $0.68 \mathrm{mg} / \mathrm{L}$, respectively. The decreasing extent of different depths showed a different trend in 2018 compared to that in 2017. This difference between 2017 and 2018 may due to the tighter compaction of soil and changes in soil environment.

RC-CI treatment significantly increased the average $\mathrm{NH}_{4}{ }^{+}-\mathrm{N}$ concentration of the whole rice growth season in the depth of $0 \sim 18,28 \sim 36$ and $36 \sim 54 \mathrm{~cm}$ in both years compared with FI treatment. However, the DP-SM treatment decreased the the average $\mathrm{NH}_{4}{ }^{+}-\mathrm{N}$ concentration of the whole rice growth season in different depths, but the difference did not reach a significant level. Alternate wetting and drying of RC-CI and DP-SM dramatically changed the soil physical environment, causing frequent conversion between aerobic and anaerobic $[5,43]$. The alternate wetting and drying cycle of RC-CI was more frequent, and for DP-SM, was less frequent, as it kept more days of dry conditions. The microbial processes of mineralization, nitrification, and denitrification varied greatly when the water condition changed [12], which in turn impacted the distribution of nitrogen in soil water.

\subsubsection{Vertical Migration of $\mathrm{NO}_{3}{ }^{-}-\mathrm{N}$}

Figure 5 shows the changes of average $\mathrm{NO}_{3}{ }^{-}-\mathrm{N}$ concentration of different rice growth stages and the whole growth season in soil water at the depth of 18, 36 and $54 \mathrm{~cm}$ in 2017 and 2018. The average $\mathrm{NO}_{3}{ }^{-}-\mathrm{N}$ concentration value of different depths was obviously smaller than $\mathrm{NH}_{4}{ }^{+}-\mathrm{N}$ concentration. The average $\mathrm{NO}_{3}{ }^{-}-\mathrm{N}$ concentration during each growth stage (except for the heading-flowering stage of 2018), as well as the average concentration during the whole growth stage, all showed a law of increasing from top to bottom in 2017 and 2018. $\mathrm{NO}_{3}{ }^{-}-\mathrm{N}$ is negatively charged and not easily adsorbed by soil colloids [5,44]. As a result, $\mathrm{NO}_{3}{ }^{-}-\mathrm{N}$ is easy to move down with the water to the lower soil layer and cause groundwater pollution.
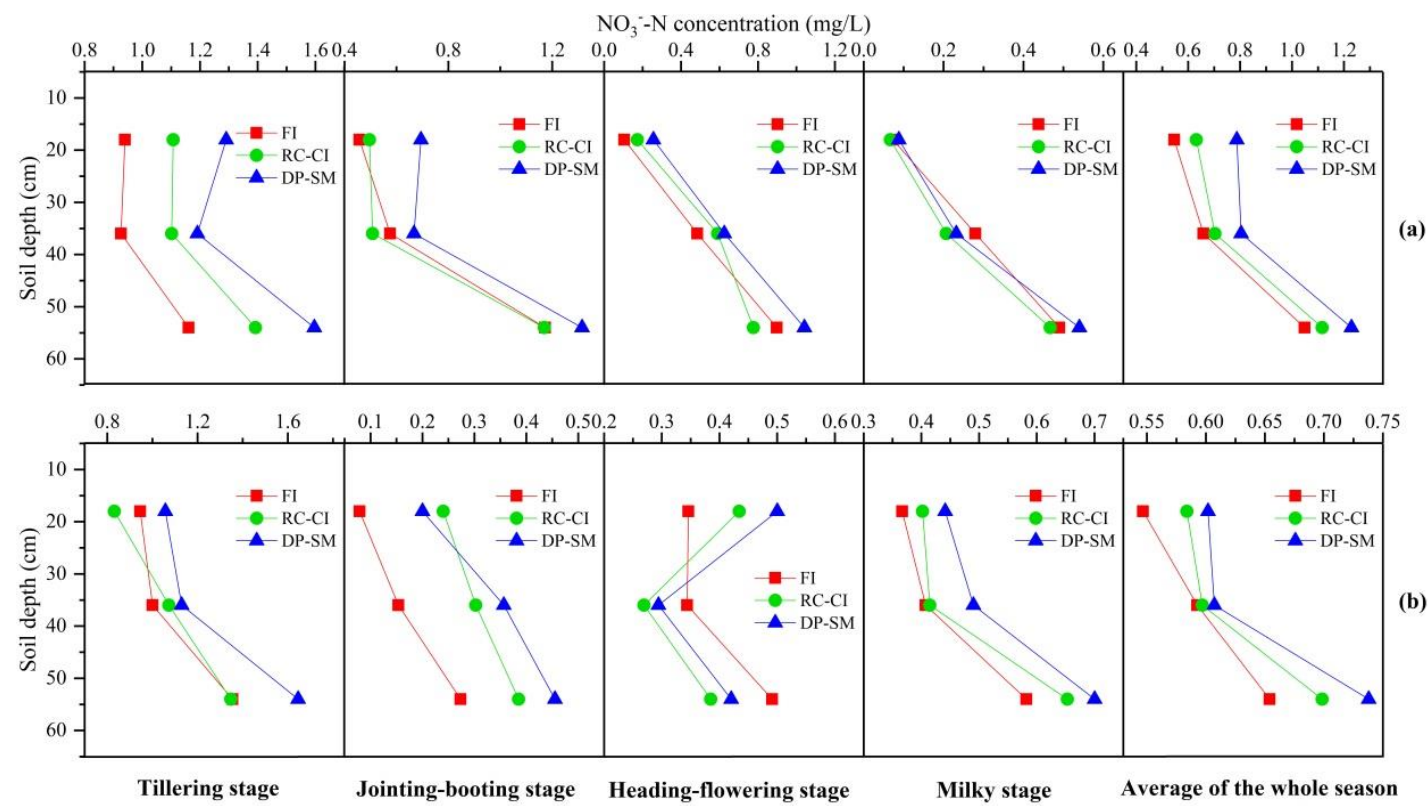

Figure 5. Vertical change of $\mathrm{NO}_{3}{ }^{-}-\mathrm{N}$ concentration in soil water at the depth of 18,36 and $54 \mathrm{~cm}$ in (a) 2017 and (b) 2018 .

In 2017, the $\mathrm{NO}_{3}{ }^{-}-\mathrm{N}$ concentration during the whole growth season of the $0 \sim 18 \mathrm{~cm}$ depth soil water were $0.55 \mathrm{mg} / \mathrm{L}$ for FI, $0.63 \mathrm{mg} / \mathrm{L}$ for RC-CI, $0.79 \mathrm{mg} / \mathrm{L}$ for DP-SM, respectively. The $\mathrm{NO}_{3}{ }^{-}-\mathrm{N}$ concentration in soil water of $18 \sim 36 \mathrm{~cm}$ depth increased to $0.66 \mathrm{mg} / \mathrm{L}$ for FI, $0.70 \mathrm{mg} / \mathrm{L}$ for RC-CI, $0.80 \mathrm{mg} / \mathrm{L}$ for DP-SM, respectively. Then, the $\mathrm{NO}_{3}{ }^{-}-\mathrm{N}$ concentration in soil water of $36 \sim 54 \mathrm{~cm}$ depth 
sharply increased by $55.22 \%$ for FI, $58.73 \%$ for RC-CI, $52.77 \%$ for DP-SM compared to that of $18 \sim 36 \mathrm{~cm}$ depth, respectively. In 2018, the $\mathrm{NO}_{3}{ }^{-}-\mathrm{N}$ concentration of all treatments slightly increased from $0 \sim 18 \mathrm{~cm}$ depth to $18 \sim 36 \mathrm{~cm}$ depth and then sharply increased to $0.65 \mathrm{mg} / \mathrm{L}$ for FI, $0.70 \mathrm{mg} / \mathrm{L}$ for RC-CI, $0.74 \mathrm{mg} / \mathrm{L}$ for DP-SM, respectively. The increasing extent of $18 \sim 36 \mathrm{~cm}$ depth to $36 \sim 54 \mathrm{~cm}$ depth was significantly higher than that of $0 \sim 18 \mathrm{~cm}$ depth to $18 \sim 36 \mathrm{~cm}$ depth in both years. The average $\mathrm{NO}_{3}{ }^{-}-\mathrm{N}$ concentration of the whole rice growth season in all depths followed a law of DP-SM $>$ RC-CI $>$ FI in both years. With the increase of soil depth, the $\mathrm{NH}_{4}{ }^{+}-\mathrm{N}$ concentration decreased and the $\mathrm{NO}_{3}{ }^{-}-\mathrm{N}$ produced by nitrification gradually accumulated, increasing the $\mathrm{NO}_{3}{ }^{-}-\mathrm{N}$ concentration in the lower soil water. The DP-SM and RC-CI treatments promoted the formation of aerobic conditions in soil and increased dissolved oxygen in soil water throughout the growth period compared with FI treatment. These changes accelerated the nitrification process, producing more $\mathrm{NO}_{3}{ }^{-}-\mathrm{N}[35,45]$. And the DP-SM treatment kept more days of dry condition than RC-CI, thus the $\mathrm{NO}_{3}{ }^{-}-\mathrm{N}$ concentration of different depths under DP-SM was much higher than that of RC-CI.

\subsubsection{Vertical Migration of TN}

The changes average TN concentrations of different growth stages and the whole growth season in soil water at the depth of 18, 36 and $54 \mathrm{~cm}$ in 2017 and 2018 are shown on Figure 6. TN concentrations in soil water of different depths varied mostly in the same pattern as that of $\mathrm{NH}_{4}{ }^{+}-\mathrm{N}$ concentration, because $\mathrm{NH}_{4}{ }^{+}-\mathrm{N}$ occupied most of the nitrogen in soil water quantitatively. A decreasing trend of the average TN concentration from top to bottom was also shown during each growth stage, as well as throughout the whole growth season in both years. The TN concentration in all depths of soil showed a decreasing trend with the rice growth process and maintained high values in tillering stage and jointing-booting stage in both years.

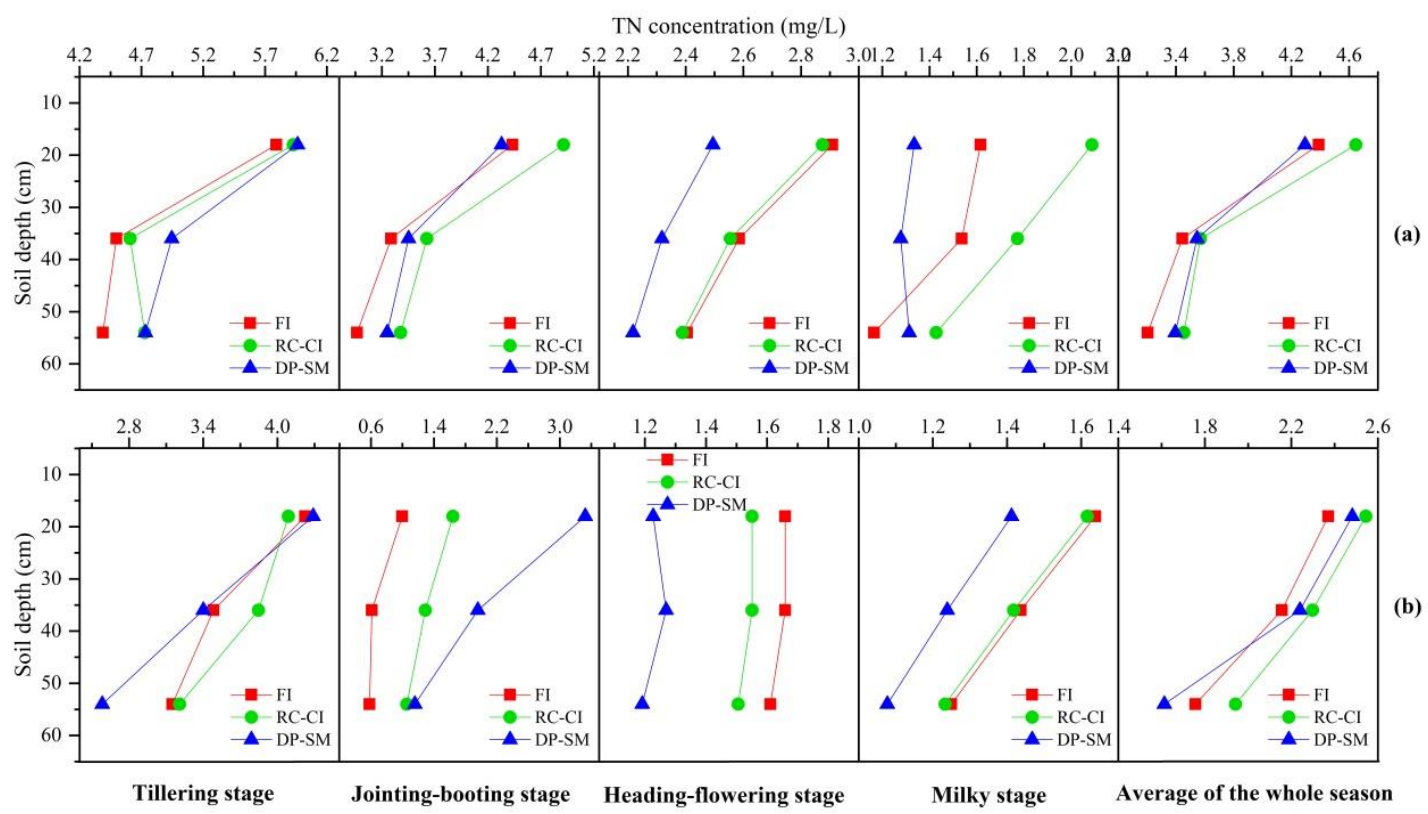

Figure 6. Vertical change of TN concentration in soil water at the depth of 18, 36 and $54 \mathrm{~cm}$ in (a) 2017 and (b) 2018.

RC-CI increased the average TN concentration of the whole growth season in soil water at $0 \sim 18 \mathrm{~cm}$ depth, 18 36 cm depth and 36 54 cm depth compared with FI in both years. The increase percentage was $5.85 \%, 3.61 \%$ and $7.83 \%$ at $0 \sim 18 \mathrm{~cm}$ depth, 18 36 cm depth and $36 \sim 54 \mathrm{~cm}$ depth in 2017, respectively, and in 2018 the percentage was $7.34 \%, 6.58 \%$ and $10.52 \%$. However, the average TN concentration of the whole growth season in soil water of DP-SM showed different results in two years. In 2017, DP-SM decreased the average TN concentration of the whole growth season in soil water at $0 \sim 18 \mathrm{~cm}$ 
depth by $2.17 \%$ but increased by $2.93 \%$ and $5.96 \%$ at $18 \sim 36 \mathrm{~cm}$ depth and $36 \sim 54 \mathrm{~cm}$ depth compared with FI. In 2018, DP-SM showed an increase of $4.68 \%$, an increase of $3.88 \%$ and a decrease of $8.19 \%$ at the depth of $0 \sim 18 \mathrm{~cm}, 18 \sim 36 \mathrm{~cm}$ and $36 \sim 54 \mathrm{~cm}$ compared with FI, respectively. The fluctuation of the concentrations of all forms of nitrogen in soil water varied with the greatly variation of water regime in the cultivated horizon, result from the changes of nitrification-denitrification-mineralization process caused by the alternative drying and wetting cycles of RC-CI and DP-SM [12,27]. The risk of leaching caused by the high TN concentration in different soil depth should be fully considered.

\subsection{The Variation of $\mathrm{NH}_{4}{ }^{+}-\mathrm{N}, \mathrm{NO}_{3}{ }^{-}-\mathrm{N}$ and $\mathrm{TN}$ Concentration in Percolation Water}

\subsubsection{The Variation of $\mathrm{NH}_{4}{ }^{+}-\mathrm{N}$ Concentration in Percolation Water}

The $\mathrm{NH}_{4}{ }^{+}-\mathrm{N}$ concentration in percolation water during the whole rice growth stage under different irrigation regimes is shown in Figure 7. $\mathrm{NH}_{4}{ }^{+}-\mathrm{N}$ concentration in percolation water increased after each fertilizer application both in 2017 and 2018, indicating that nitrogen fertilizer application was the predominant factor of $\mathrm{NH}_{4}{ }^{+}-\mathrm{N}$ concentration. The peak values of $\mathrm{NH}_{4}{ }^{+}-\mathrm{N}$ concentration in percolation water after fertilization followed an order of RC-CI $>$ FI $>$ DP-SM in both years. The $\mathrm{NH}_{4}{ }^{+}-\mathrm{N}^{-}$ concentration in percolation water of RC-CI was higher than FI and DP-SM during most of the rice growth stage in both years. The $\mathrm{NH}_{4}{ }^{+}-\mathrm{N}$ concentration of DP-SM in 2017 was lower than FI during most days but it showed a trend of higher in early growth stage and lower in late growth stage in 2018. Yang et al. reported that straw return significantly increased the N uptake of rice plant [35], which may be a cause of the low concentration value of DP-SM.

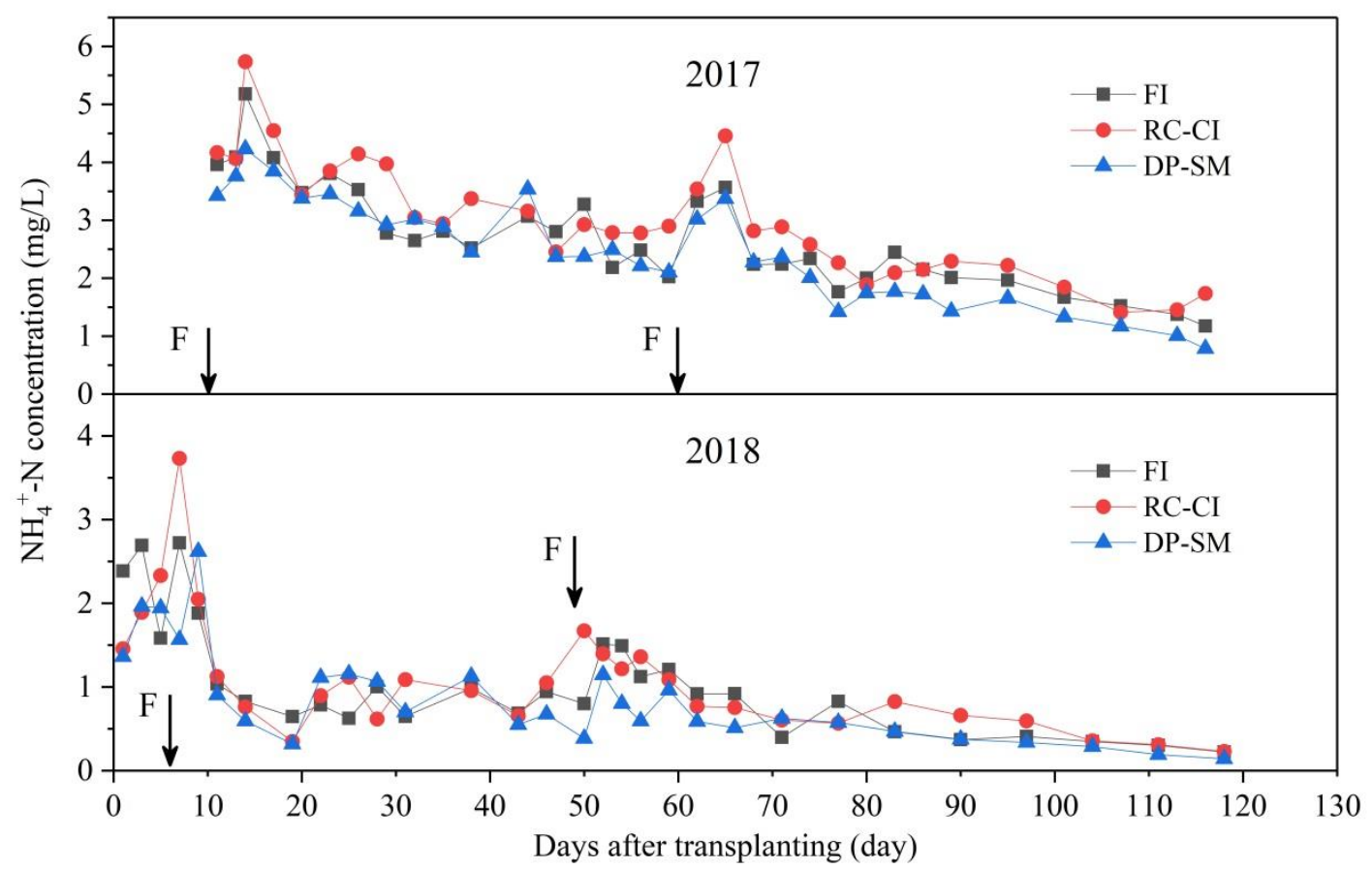

Figure 7. $\mathrm{NH}_{4}{ }^{+}-\mathrm{N}$ concentrations in percolation water under different irrigation regimes (The arrows indicate fertilization).

In 2017, the $\mathrm{NH}_{4}{ }^{+}-\mathrm{N}$ concentration in percolation water varied from $1.17 \mathrm{mg} / \mathrm{L}$ to $5.18 \mathrm{mg} / \mathrm{L}$ for FI, $1.41 \mathrm{mg} / \mathrm{L}$ to $5.74 \mathrm{mg} / \mathrm{L}$ for RC-CI, $0.78 \mathrm{mg} / \mathrm{L}$ to $4.23 \mathrm{mg} / \mathrm{L}$ for DP-SM, respectively. Three days after the tillering fertilizer was applied, the $\mathrm{NH}_{4}{ }^{+}-\mathrm{N}$ concentration in percolation water of all the treatments reached the peak value $(5.18 \mathrm{mg} / \mathrm{L}$ for FI, $5.74 \mathrm{mg} / \mathrm{L}$ for RC-CI and $4.23 \mathrm{mg} / \mathrm{L}$ for DP-SM). The other peak values of $3.57 \mathrm{mg} / \mathrm{L}$ for FI, $4.46 \mathrm{mg} / \mathrm{L}$ for RC-CI, $3.37 \mathrm{mg} / \mathrm{L}$ for DP-SM were observed five days after the panicle fertilizer was applied. The $\mathrm{NH}_{4}{ }^{+}-\mathrm{N}$ concentration in percolation water in re-green 
stage was not observed in 2017, but was in 2018, so the maximum concentration was monitored in re-green stage in 2018. In 2018, the $\mathrm{NH}_{4}{ }^{+}-\mathrm{N}$ concentration in percolation water varied from $0.22 \mathrm{mg} / \mathrm{L}$ to $2.88 \mathrm{mg} / \mathrm{L}$ for FI, $0.23 \mathrm{mg} / \mathrm{L}$ to $4.20 \mathrm{mg} / \mathrm{L}$ for RC-CI, $0.14 \mathrm{mg} / \mathrm{L}$ to $2.62 \mathrm{mg} / \mathrm{L}$ for DP-SM, respectively. The $\mathrm{NH}_{4}{ }^{+}$-N concentration in percolation water of FI and RC-CI reached the peak value of $2.72 \mathrm{mg} / \mathrm{L}$ and $3.73 \mathrm{mg} / \mathrm{L}$ the day after the tillering fertilizer was applied. But for RC-CI, the peak value of $2.62 \mathrm{mg} / \mathrm{L}$ was observed three days after the tillering fertilizer application. The panicle fertilizer was applied on 49 days after transplanting and a peak value of $1.67 \mathrm{mg} / \mathrm{L}$ under RC-CI was monitored the next day. Peak values of $1.51 \mathrm{mg} / \mathrm{L}$ for FI, $1.15 \mathrm{mg} / \mathrm{L}$ for DP-SM were observed three days after the panicle fertilizer application.

In general, $\mathrm{NH}_{4}{ }^{+}-\mathrm{N}$ is less likely to leach than $\mathrm{NO}_{3}{ }^{-}-\mathrm{N}$ as a result of the high soil adsorption the short migration distance of $\mathrm{NH}_{4}{ }^{+}-\mathrm{N}[44,46]$. However, the large amount of residual $\mathrm{NH}_{4}{ }^{+}-\mathrm{N}$ would be rapidly lost when the soil absorption of $\mathrm{NH}_{4}{ }^{+}-\mathrm{N}$ becomes saturated. Tan et al. [12] and Peng et al. [47] also reported similar laws of change as RC-CI under alternate wetting and drying irrigation and controlled irrigation, respectively. Their irrigation control threshold was less different from RC-CI but significantly higher than DP-SM, indicating that the less irrigation and straw return condition greatly affected the $\mathrm{N}$ concentration in percolation water.

\subsubsection{The Variation of $\mathrm{NO}_{3}{ }^{-}-\mathrm{N}$ Concentration in Percolation Water}

$\mathrm{NO}_{3}{ }^{-}-\mathrm{N}$ concentrations in percolation water during the whole rice growth stage under different irrigation regimes are shown in Figure 8. They varied differently from the $\mathrm{NH}_{4}{ }^{+}-\mathrm{N}$ concentrations in percolation water. The $\mathrm{NO}_{3}{ }^{-}-\mathrm{N}$ concentrations in the percolation water didn't respond strongly to the application of fertilizer. In both years, the $\mathrm{NO}_{3}{ }^{-}-\mathrm{N}$ concentrations in percolation water showed a regular pattern of DP-SM $>$ RC-CI $>$ FI during most of the rice growth stage.

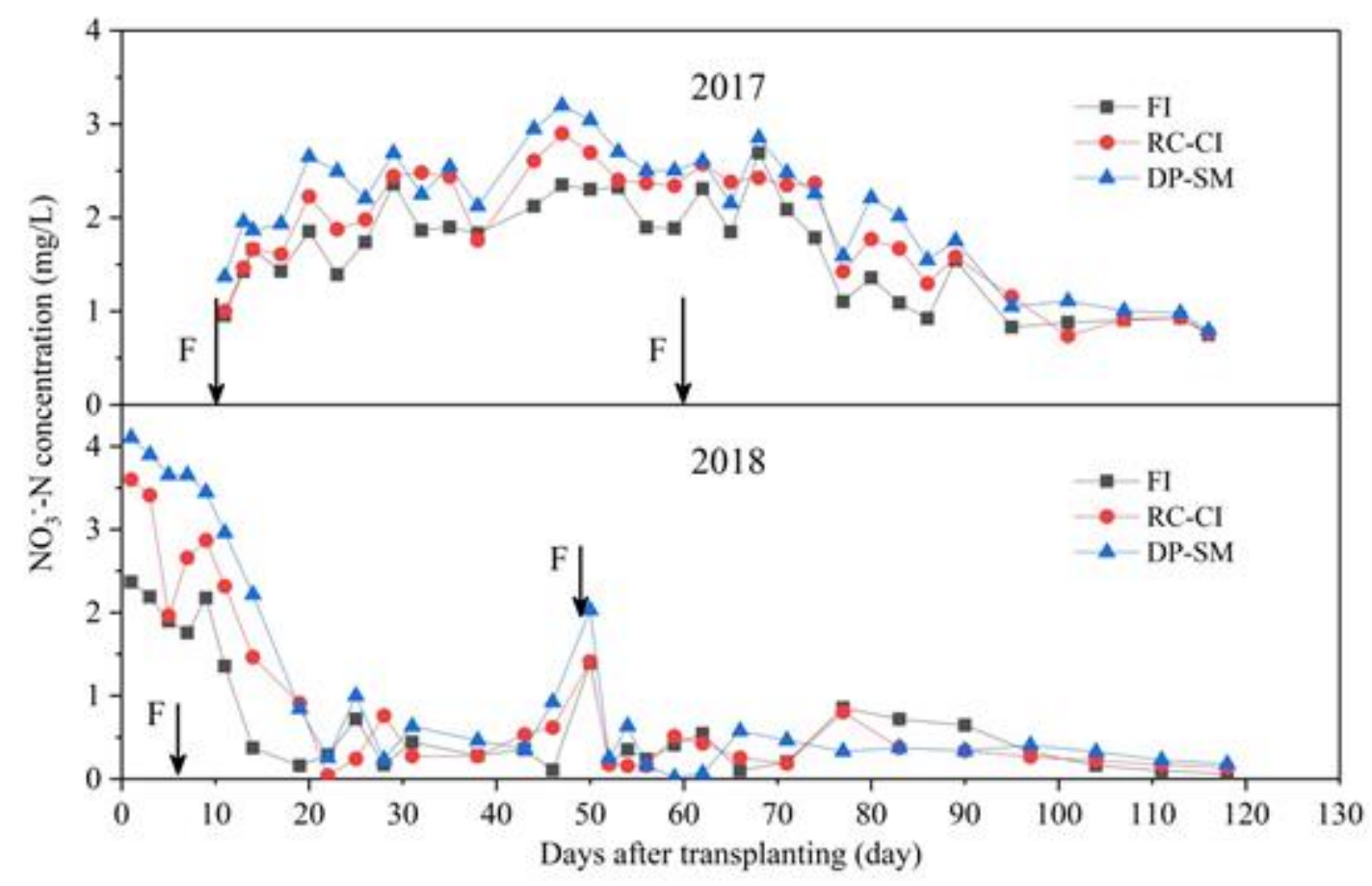

Figure 8. $\mathrm{NO}_{3}{ }^{-}-\mathrm{N}$ concentrations in percolation water under different irrigation regimes (The arrows indicate fertilization).

In 2017, the $\mathrm{NO}_{3}{ }^{-}-\mathrm{N}$ concentration in percolation water ranged between 0.75 and $2.69 \mathrm{mg} \mathrm{L}^{-1}$ for FI, 0.74 and $2.90 \mathrm{mg} \mathrm{L}^{-1}$ for RC-CI, 0.80 and $3.20 \mathrm{mg} \mathrm{L}^{-1}$ for FI, respectively. They maintained high values from late tillering stage to early heading-flowering stage and maintained low values in other rice growth stage. The beginning of the high values of $\mathrm{NO}_{3}{ }^{-}-\mathrm{N}$ concentrations was synchronized 
with the beginning of alternating wet and dry, which may promote the nitrification and produce more $\mathrm{NO}_{3}{ }^{-}-\mathrm{N}[5]$.

In 2018, the $\mathrm{NO}_{3}{ }^{-}-\mathrm{N}$ concentrations in percolation water maintained high values in the re-greening stage and then sharply decreased in early tillering stage. Except a transient peak value the day after panicle fertilizer application, the $\mathrm{NO}_{3}{ }^{-}-\mathrm{N}$ concentrations in percolation water maintained low values (under $1 \mathrm{mg} / \mathrm{L}$ ) in the rest of the rice growth stage. After the rice harvest in 2017, nothing was planted in the soil and the soil was in a state of long-term explosion to air, resulting in the high values in the re-greening stage in 2018. The soil was compacted along one year of compaction before rice was transplanted in 2018, and the gas permeability of the soil deteriorated. As a result, the $\mathrm{NO}_{3}{ }^{-}-\mathrm{N}$ concentrations in percolation water maintained low values after early tillering stage in 2018.

Long-term flooding in the paddy field of FI limited the nitrogen process of nitrification while strengthened the denitrification. However, the wetting and drying cycles of RC-CI and DP-SM changed paddy soil environment, increasing the oxygen flux from atmosphere to the soil. $\mathrm{The} \mathrm{NO}_{3}{ }^{-} \mathrm{-N}$ concentrations in percolation water of RC-CI and DP-SM was much higher in this condition as a result of the accelerated nitrification process [12].

The highest $\mathrm{NO}_{3}{ }^{-}-\mathrm{N}$ concentrations among treatments were observed under DP-SM. Except for the reason of wet-dry alternation in the soil, the straw-return condition under DP-SM may contribute to the high $\mathrm{NO}_{3}{ }^{-}-\mathrm{N}$ concentration. The straw return increased the organic matter in the field and greatly influenced the soil processes and the soil environment. Eagle et al. [48] and Yang et al. [35] reported that straw incorporation had great potential for significant residual effects on soil nutrient supply by increasing microbial biomass and nitrogen mineralization, higher soil organic carbon and nitrogen levels. Wang et al. [49] found that the straw can enhance microbial N immobilization due to its high $\mathrm{C} / \mathrm{N}$ ratio. These changes provided favorable conditions for the nitrification process, which may contribute to the high $\mathrm{NO}_{3}{ }^{-}-\mathrm{N}$ concentration under DP-SM treatment. Furthermore, different straw returning modes may show different effects on soil carbon-nitrogen relationship to some extent [34]. In the present study, the straw maintaining as mulch over the surface, incorporation procedure of straw, such as plowing the straw to different soil depths, will be considered in future study.

\subsubsection{The Variation of TN Concentration in Percolation Water}

With regard to $\mathrm{TN}$, the concentrations varied mostly in the same pattern as that of $\mathrm{NH}_{4}{ }^{+}-\mathrm{N}$ which was the major form of the nitrogen in percolation water (Figure 9). The peak values of TN concentration of RC-CI in percolation water after fertilization were also the highest among treatments in both years, as well as the TN concentration in percolation water of RC-CI during most of the rice growth stage. 


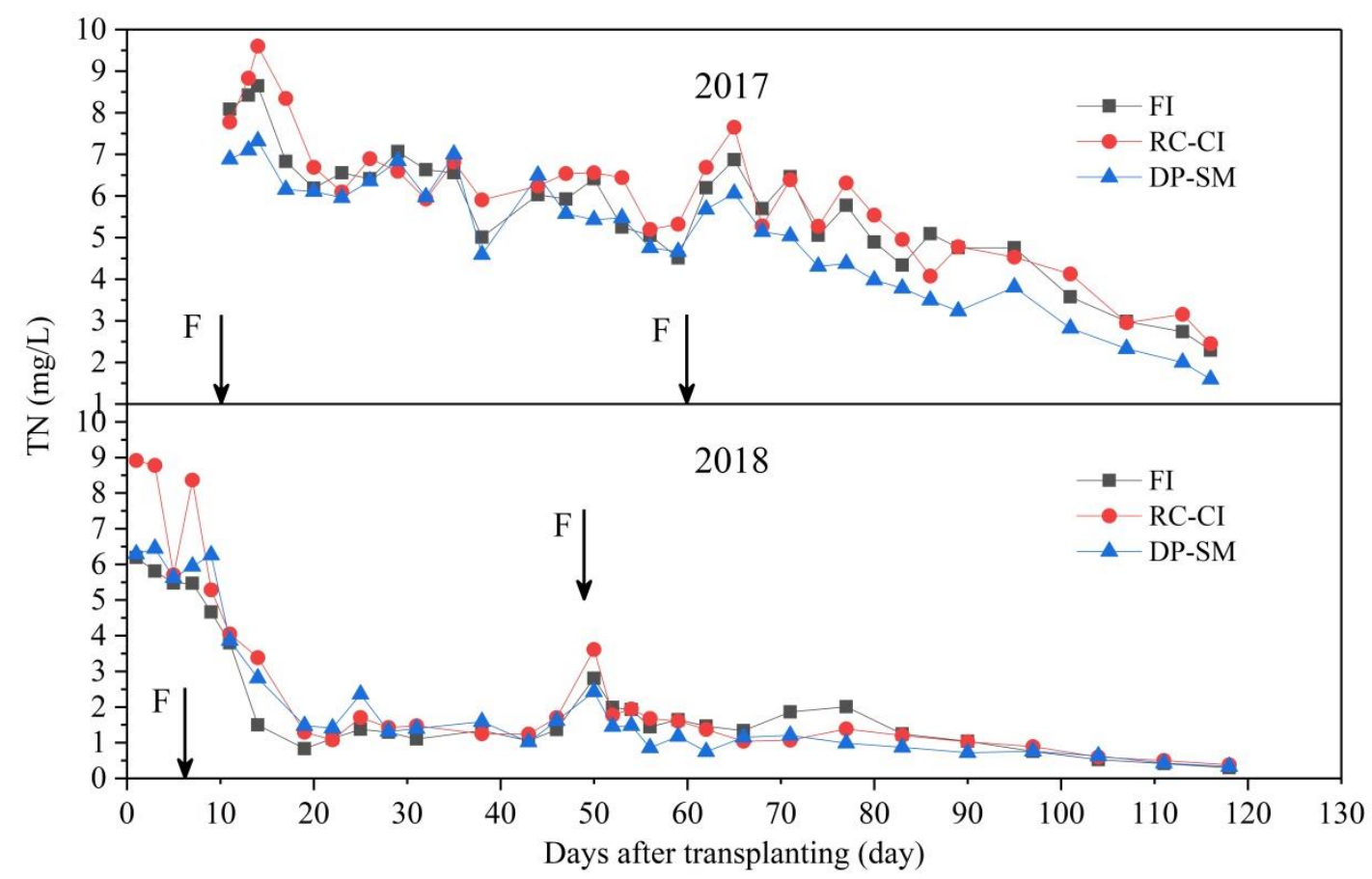

Figure 9. $\mathrm{TN}$ concentrations in percolation water under different irrigation regimes (arrows indicate fertilization).

In 2017, the TN concentrations in percolation water ranged from 2.29 to $8.64 \mathrm{mg} / \mathrm{L}$ for FI, 2.45 to $9.60 \mathrm{mg} / \mathrm{L}$ for RC-CI and 1.60 to $7.32 \mathrm{mg} / \mathrm{L}$ for DP-SM, respectively. There were peak values of $8.65 \mathrm{mg} / \mathrm{L}$ for FI, $9.60 \mathrm{mg} / \mathrm{L}$ for RC-CI, $7.32 \mathrm{mg} / \mathrm{L}$ for DP-SM four days after panicle fertilizer was applied and peak values of $6.87 \mathrm{mg} / \mathrm{L}$ for FI, $7.65 \mathrm{mg} / \mathrm{L}$ for RC-CI, $6.06 \mathrm{mg} / \mathrm{L}$ for DP-SM five days after panicle fertilizer was applied. In 2018, the TN concentration in percolation water maintained high in re-green stage. The TN concentration in the percolation water ranged between 0.30 and $6.62 \mathrm{mg} / \mathrm{L}$ for FI, 0.38 and $10.60 \mathrm{mg} / \mathrm{L}$ for RC-CI, 0.33 and $6.54 \mathrm{mg} / \mathrm{L}$ for DP-SM, respectively. The peak values of $5.47 \mathrm{mg} / \mathrm{L}$ for FI, $8.36 \mathrm{mg} / \mathrm{L}$ for RC-CI in tillering stage were observed the day after the tillering fertilizer application whereas the peak value of $6.36 \mathrm{mg} / \mathrm{L}$ for DP-SM came two days later. However, the peak values after panicle fertilization ( $2.80 \mathrm{mg} / \mathrm{L}$ for FI, $3.61 \mathrm{mg} / \mathrm{L}$ for RC-CI, $2.42 \mathrm{mg} / \mathrm{L}$ for DP-SM) were all monitored the next day. RC-CI increased the TN concentration in the percolation water during most rice growth stage in both years. Similar results were reported by Katsura et al. [50] and Tan et al. [5,12].

\subsection{The Amount of Nitrogen Leaching Losses}

The amount of $\mathrm{N}$ leaching losses was determined based on the volume of percolation water and $\mathrm{N}$ concentrations of the sampling water collected through the hydrovalve. The $\mathrm{N}$ concentrations were assumed to be average concentrations during each sampling interval. Table 4 shows the total losses of $\mathrm{NH}_{4}{ }^{+}-\mathrm{N}, \mathrm{NO}_{3}{ }^{-}-\mathrm{N}$ and $\mathrm{TN}$ through leaching during each rice growth stage over two years (addition of 2017 and 2018). 
Table 4. The amount of nitrogen leaching losses during different rice growth stages (Addition of 2017 and $2018, \mathrm{~kg} / \mathrm{ha}$ ).

\begin{tabular}{cccccccc}
\hline \multirow{2}{*}{ N Form } & Treatments & $\begin{array}{c}\text { Tillering } \\
\text { Stage }\end{array}$ & $\begin{array}{c}\text { Jointing-Booting } \\
\text { Stage }\end{array}$ & $\begin{array}{c}\text { Heading-Flowering } \\
\text { Stage }\end{array}$ & Milky Stage & $\begin{array}{c}\text { Ripening } \\
\text { Stage }\end{array}$ & $\begin{array}{c}\text { Total } \\
\text { Season }\end{array}$ \\
\hline \multirow{2}{*}{$\mathrm{NH}_{4}{ }^{+}-\mathrm{N}$} & FI & $5.05 \mathrm{a}$ & $4.12 \mathrm{a}$ & $1.60 \mathrm{a}$ & $0.61 \mathrm{a}$ & $0.43 \mathrm{a}$ & $11.82 \mathrm{a}$ \\
& RC-CI & $3.06 \mathrm{~b}$ & $3.00 \mathrm{~b}$ & $1.00 \mathrm{~b}$ & $0.55 \mathrm{a}$ & $0.26 \mathrm{~b}$ & $7.86 \mathrm{~b}$ \\
& DP-SM & $1.67 \mathrm{c}$ & $1.47 \mathrm{c}$ & $0.32 \mathrm{c}$ & $0.11 \mathrm{~b}$ & $0.07 \mathrm{c}$ & $3.64 \mathrm{c}$ \\
\hline \multirow{2}{*}{$\mathrm{NO}_{3}{ }^{-}-\mathrm{N}$} & $\mathrm{FI}$ & $2.65 \mathrm{a}$ & $2.87 \mathrm{a}$ & $1.11 \mathrm{a}$ & $0.39 \mathrm{a}$ & $0.28 \mathrm{a}$ & $7.29 \mathrm{a}$ \\
& RC-CI & $1.92 \mathrm{~b}$ & $1.99 \mathrm{~b}$ & $0.78 \mathrm{~b}$ & $0.28 \mathrm{~b}$ & $0.16 \mathrm{~b}$ & $5.12 \mathrm{~b}$ \\
& DP-SM & $1.50 \mathrm{c}$ & $1.27 \mathrm{c}$ & $0.35 \mathrm{c}$ & $0.09 \mathrm{c}$ & $0.06 \mathrm{c}$ & $3.27 \mathrm{c}$ \\
\hline \multirow{2}{*}{$\mathrm{TN}$} & FI & $9.86 \mathrm{a}$ & $8.12 \mathrm{a}$ & $3.82 \mathrm{a}$ & $1.37 \mathrm{a}$ & $0.85 \mathrm{a}$ & $24.02 \mathrm{a}$ \\
& RC-CI & $6.05 \mathrm{~b}$ & $5.53 \mathrm{~b}$ & $2.21 \mathrm{~b}$ & $1.12 \mathrm{~b}$ & $0.50 \mathrm{~b}$ & $15.42 \mathrm{~b}$ \\
& DP-SM & $3.47 \mathrm{c}$ & $2.86 \mathrm{c}$ & $0.72 \mathrm{c}$ & $0.24 \mathrm{c}$ & $0.13 \mathrm{c}$ & $7.42 \mathrm{c}$ \\
\hline
\end{tabular}

Note: Different letters $(\mathrm{a}, \mathrm{b}, \mathrm{c})$ in each column of the same $\mathrm{N}$ form represent significant differences, among the treatments $(p<0.05)$.

RC-CI and DP-SM treatments remarkably reduced the amount of $\mathrm{NH}_{4}{ }^{+}-\mathrm{N}, \mathrm{NO}_{3}{ }^{-}-\mathrm{N}$ and TN leaching losses compared to FI. The $\mathrm{NH}_{4}{ }^{+}-\mathrm{N}, \mathrm{NO}_{3}{ }^{-}-\mathrm{N}$ and TN leaching losses for RC-CI during the whole rice growth stage were reduced by $33.50 \%, 29.77 \%$ and $35.80 \%$, respectively, compared to FI. However, the reduction percentage of $\mathrm{NH}_{4}{ }^{+}-\mathrm{N}, \mathrm{NO}_{3}{ }^{-}-\mathrm{N}$ and $\mathrm{TN}$ leaching losses for DP-SM were $69.20 \%, 55.14 \%$ and $69.11 \%$, respectively, compared to FI. These were also the minimum values among the different water treatments. Tan et al. [12] and Katsura et al. [50] found that the TN concentration in percolation water of alternate wetting and drying irrigation (similar to RC-CI ) was significantly higher than that of FI and the significant decrease of percolation water volumes under water-saving irrigation led to the decreasing leaching losses, which was similar to the results in our experiments.

The amount of $\mathrm{NH}_{4}{ }^{+}-\mathrm{N}$ leaching losses was $11.82 \mathrm{~kg} / \mathrm{ha}$ for FI, $7.86 \mathrm{~kg} / \mathrm{ha}$ for RC-CI and $3.64 \mathrm{~kg} / \mathrm{ha}$ for DP-SM, respectively, accounting for $49.21 \%, 50.97 \%$ and $49.06 \%$ of that of TN. Yang et al. [51,52] also reported that was the main form of nitrogen leaching in paddy fields in Taihu Lake Region of China. For $\mathrm{NO}_{3}{ }^{-}-\mathrm{N}$, the amount was $7.29 \mathrm{~kg} /$ ha for FI, $5.12 \mathrm{~kg} / \mathrm{ha}$ for RC-CI, $3.27 \mathrm{~kg} / \mathrm{ha}$ for DP-SM, respectively. The $\mathrm{NO}_{3}{ }^{-}$-N leaching losses of FI and RC-CI accounted for $30.35 \%$ and $33.20 \%$ of TN leaching losses, respectively. However, the $\mathrm{NO}_{3}{ }^{-}-\mathrm{N}$ leaching losses of DP-SM was $44.07 \%$ of that of the TN leaching losses. The drier condition of DP-SM than RC-CI treatment and the straw-covering condition created more aerobic conditions. The nitrification process was accelerated, and more $\mathrm{NO}_{3}{ }^{-}-\mathrm{N}$ was produced under these conditions $[35,45]$, contributing to the high ratio of nitrate nitrogen. The $\mathrm{NH}_{4}{ }^{+}-\mathrm{N}, \mathrm{NO}_{3}{ }^{-}-\mathrm{N}$ and TN leaching losses in tillering stage and jointing-booting stage accounted for $74.85 \% \sim 86.26 \%$ of the total amount during the whole rice growth season, which was main caused by the high value of $\mathrm{N}$ concentrations during this period. And the absorbing ability of plants was limited at the early growth period $[37,53]$. It is necessary to take effective measures to reduce $\mathrm{N}$ leaching losses during the tillering and jointing-booting stages, i.e., the two critical periods.

\section{Conclusions}

Water use, rice yield, vertical migration and leaching of nitrogen in paddy fields under water-saving and straw return conditions were very different from those under FI (CK). Two water-saving irrigation regimes, RC-CI and DP-SM, were investigated during the two-year experiment. Under the present experimental conditions, the main conclusions were as follows:

1. RC-CI and DP-SM both showed significant water-saving effect, as they significantly decreased the irrigation input and percolation water volume compared with FI. RC-CI increased the rice yield by $8.23 \% \sim 12.26 \%$ while DP-SM decreased the rice yield by $8.98 \% \sim 15.24 \%$ compared with FI, indicating the better production-increasing benefits of RC-CI.

2. The average $\mathrm{NH}_{4}{ }^{+}-\mathrm{N}$ and $\mathrm{TN}$ concentration showed a law of decreasing from top to bottom in soil water of $0 \sim 54 \mathrm{~cm}$ depth while the concentration of $\mathrm{NO}_{3}{ }^{-}-\mathrm{N}$ presented the opposite rule. RC-CI significantly presented the highest average $\mathrm{NH}_{4}{ }^{+}-\mathrm{N}$ and TN concentration of the whole 
rice growth season in the depth of $0 \sim 18,28 \sim 36$ and 36 54 cm compared with FI treatment while DP-SM presented the highest average $\mathrm{NO}_{3}{ }^{-}-\mathrm{N}$ concentration of different depth.

3. Peak values of $\mathrm{NH}_{4}{ }^{+}-\mathrm{N}$ and $\mathrm{TN}$ concentration in percolation water were observed $1 \sim 5$ days after each fertilizer application, indicating that nitrogen fertilizer application was the predominant factor of $\mathrm{NH}_{4}{ }^{+}-\mathrm{N}$ and $\mathrm{TN}$ concentration. However, the $\mathrm{NO}_{3}{ }^{-}-\mathrm{N}$ concentrations in the percolation water didn't respond strongly to the application of fertilizer.

4. The TN and $\mathrm{NH}_{4}{ }^{+}-\mathrm{N}$ concentrations in percolation water of $\mathrm{RC}-\mathrm{CI}$ during most of the rice growth stage were the highest among treatments in both years and DP-SM showed a trend of decreasing $\mathrm{TN}$ and $\mathrm{NH}_{4}{ }^{+}-\mathrm{N}$ concentrations. The $\mathrm{NO}_{3}{ }^{-}-\mathrm{N}$ concentrations in percolation water showed a regular pattern of DP-SM $>$ RC-CI $>$ FI during most of the rice growth stage.

5. RC-CI and DP-SM remarkably reduced the amount of $\mathrm{N}$ leaching losses compared to FI as a result of the significant decrease of percolation water volumes. $\mathrm{NH}_{4}{ }^{+}-\mathrm{N}$ was the main form of the nitrogen leaching losses in percolation water, occupying $49.06 \% \sim 50.97 \%$ of TN leaching losses. The $\mathrm{NO}_{3}{ }^{-}-\mathrm{N}$ leaching losses and accounted for $30.35 \%$ for FI, 33.20\% for RC-CI and $44.07 \%$ for DP-SM of TN leaching losses, respectively, and the driest condition of DP-SM and the straw-covering condition accelerated the nitrification process most. The $\mathrm{N}$ leaching losses in tillering stage and jointing-booting stage accounted for $74.85 \% \sim 86.26 \%$ of the total amount during the whole rice growth season, implying that effective measures are necessary to be taken to reduce $\mathrm{N}$ leaching losses the two critical periods.

Great potential for RC-CI and DP-SM exists in the lower reaches of the Yangtze River, China. Future research will focus on optimizing irrigation indicators and straw return combined with proper fertilization management to achieve a comprehensive goal of water-saving, increasing production and less nutrient loss.

Author Contributions: Data curation, C.Z. and Y.W.; Formal analysis, C.Z. and Y.W.; Funding acquisition, Z.Z.; Investigation, C.Z., Z.Z. and Y.W.; Methodology, C.Z., Z.Z. and Y.W.; Writing-original draft, C.Z.; Writing-review \& editing, Z.Z. and R.M.

Funding: This research was funded by the National Natural Science Foundation of China, grant number 51579069 and 51879071, and the Water Resource Science Project of Jiangxi Province, grant number KT201507.

Acknowledgments: We are grateful to the help of Shurong Hao, Yongchun Pan and Zixin Wang in the design and implementation of the experiment.

Conflicts of Interest: The authors declare no conflict of interest.

\section{References}

1. Sun, Y.; Yan, F.; Sun, Y.; Xu, H.; Guo, X.; Yang, Z.; Yin, Y.; Guo, C.; Ma, J. Effects of different water regimes and nitrogen application strategies on grain filling characteristics and grain yield in hybrid rice. Arch. Agron. Soil Sci. 2017, 64, 1152-1171. [CrossRef]

2. Li, Y.; Šimünek, J.; Wang, S.; Yuan, J.; Zhang, W. Modeling of Soil Water Regime and Water Balance in a Transplanted Rice Field Experiment with Reduced Irrigation. Water 2017, 9, 248. [CrossRef]

3. Wu, X.H.; Wang, W.; Xie, X.L.; Yin, C.M.; Xie, K.J. Photosynthetic and yield responses of rice (Oryza sativa L.) to different water management strategies in subtropical China. Photosynthetica 2018, 56, 1031-1038. [CrossRef]

4. Roost, N.; Cai, X.; Molden, D.; Cui, Y. Adapting to intersectoral transfers in the Zhanghe Irrigation System, China: Part I. In-system storage characteristics. Agric. Water Manag. 2008, 95, 698-706. [CrossRef]

5. Tan, X.; Shao, D.; Gu, W.; Liu, H. Field analysis of water and nitrogen fate in lowland paddy fields under different water managements using HYDRUS-1D. Agric. Water Manag. 2015, 150, 67-80. [CrossRef]

6. Bouman, B.; Humphreys, E.; Tuong, T.; Barker, R. Rice and water. Adv. Agron. 2007, 92, 187-237.

7. Tan, X.; Shao, D.; Liu, H. Simulating soil water regime in lowland paddy fields under different water managements using HYDRUS-1D. Agric. Water Manag. 2014, 132, 69-78. [CrossRef]

8. Lin, L.; Zhang, Z.-B.; Janssen, M.; Lennartz, B. Infiltration properties of paddy fields under intermittent irrigation. Paddy Water Environ. 2014, 12, 17-24. [CrossRef] 
9. Ullah, H.; Mohammadi, A.; Datta, A. Growth, yield and water productivity of selected lowland Thai rice varieties under different cultivation methods and alternate wetting and drying irrigation. Ann. Appl. Biol. 2018, 173, 302-312. [CrossRef]

10. Shao, G.; Cui, J.; Yu, S.E.; Lu, B.; Brian, B.J.; Ding, J.; She, D. Impacts of controlled irrigation and drainage on the yield and physiological attributes of rice. Agric. Water Manag. 2015, 149, 156-165. [CrossRef]

11. Yang, S.; Sun, X.; Ding, J.; Jiang, Z.; Xu, J. Effects of biochar addition on the NEE and soil organic carbon content of paddy fields under water-saving irrigation. Environ. Sci. Pollut. Res. 2019, 26, 8303-8311. [CrossRef] [PubMed]

12. Tan, X.; Shao, D.; Liu, H.; Yang, F.; Xiao, C.; Yang, H. Effects of alternate wetting and drying irrigation on percolation and nitrogen leaching in paddy fields. Paddy Water Environ. 2012, 11, 381-395. [CrossRef]

13. Bouman, B.; Tuong, T.P. Field water management to save water and increase its productivity in irrigated lowland rice. Agric. Water Manag. 2001, 49, 11-30. [CrossRef]

14. Garg, K.K.; Das, B.S.; Safeeq, M.; Bhadoria, P.B. Measurement and modeling of soil water regime in a lowland paddy field showing preferential transport. Agric. Water Manag. 2009, 96, 1705-1714. [CrossRef]

15. Salvagiotti, F.; Miralles, D.J. Radiation interception, biomass production and grain yield as affected by the interaction of nitrogen and sulfur fertilization in wheat. Eur. J. Agron. 2008, 28, 282-290. [CrossRef]

16. Wang, J.; Fu, P.; Wang, F.; Fahad, S.; Mohapatra, P.K.; Chen, Y.; Zhang, C.; Peng, S.; Cui, K.; Nie, L.; et al. Optimizing nitrogen management to balance rice yield and environmental risk in the Yangtze River's middle reaches. Environ. Sci. Pollut. Res. 2019, 26, 4901-4912. [CrossRef]

17. Li, Y.; Šimünek, J.; Zhang, Z.; Jing, L.; Ni, L. Evaluation of nitrogen balance in a direct-seeded-rice field experiment using Hydrus-1D. Agric. Water Manag. 2015, 148, 213-222. [CrossRef]

18. Ladha, J.K.; Pathak, H.; Krupnik, T.J.; Six, J.; van Kessel, C. Efficiency of fertilizer nitrogen in cereal production: Retrospects and prospects. Adv. Agron. 2005, 87, 85-156.

19. Ju, X.-T.; Xing, G.-X.; Chen, X.-P.; Zhang, S.-L.; Zhang, L.-J.; Liu, X.-J.; Cui, Z.-L.; Yin, B.; Christie, P.; Zhu, Z.-L. Reducing environmental risk by improving $\mathrm{N}$ management in intensive Chinese agricultural systems. Proc. Natl. Acad. Sci. USA 2009, 106, 3041-3046. [CrossRef]

20. Mo'allim, A.; Kamal, M.; Muhammed, H.; Mohd Soom, M.; Mohamed Zawawi, M.; Wayayok, A.; Che Man, H. Assessment of Nutrient Leaching in Flooded Paddy Rice Field Experiment Using Hydrus-1D. Water 2018, 10, 785. [CrossRef]

21. Dou, Z.; Tang, S.; Chen, W.; Zhang, H.; Li, G.; Liu, Z.; Ding, C.; Chen, L.; Wang, S.; Zhang, H.; et al. Effects of open-field warming during grain-filling stage on grain quality of two japonica rice cultivars in lower reaches of Yangtze River delta. J. Cereal Sci. 2018, 81, 118-126. [CrossRef]

22. Zhang, Q.; Yang, Z.; Zhang, H.; Yi, J. Recovery efficiency and loss of 15N-labelled urea in a rice-soil system in the upper reaches of the Yellow River basin. Agric. Ecosyst. Environ. 2012, 158, 118-126. [CrossRef]

23. Pan, S.-G.; Huang, S.-Q.; Jing, Z.; Wang, J.-P.; Cao, C.-G.; Cai, M.-L.; Ming, Z.; Tang, X.-R. Effects of N management on yield and $\mathrm{N}$ uptake of rice in central China. J. Integr. Agric. 2012, 11, 1993-2000. [CrossRef]

24. Yan, J.; Yin, B.; Zhang, S.; Shen, Q.; Zhu, Z. Effect of nitrogen application rate on the nitrogen uptake and distribution in rice. Plant Nutr. Ferti. Sci. 2008, 14, 835-839.

25. Belder, P.; Spiertz, J.; Bouman, B.; Lu, G.; Tuong, T. Nitrogen economy and water productivity of lowland rice under water-saving irrigation. Field Crop. Res. 2005, 93, 169-185. [CrossRef]

26. Xu, J.; Liu, B.; Wang, H.; Liu, W.; Li, Y.; Dai, Y.; Lu, T. Ammonia volatilization and nitrogen leaching following top-dressing of urea from water-saving irrigated rice field: Impact of two-split surge irrigation. Paddy Water Environ. 2018, 17, 45-51. [CrossRef]

27. Gordon, H.; Haygarth, P.M.; Bardgett, R.D. Drying and rewetting effects on soil microbial community composition and nutrient leaching. Soil Biol. Biochem. 2008, 40, 302-311. [CrossRef]

28. Dong, N.M.; Brandt, K.K.; Sørensen, J.; Hung, N.N.; Van Hach, C.; Tan, P.S.; Dalsgaard, T. Effects of alternating wetting and drying versus continuous flooding on fertilizer nitrogen fate in rice fields in the Mekong Delta, Vietnam. Soil Biol. Biochem. 2012, 47, 166-174. [CrossRef]

29. Peng, S.-Z.; Yang, S.-H.; Xu, J.-Z.; Luo, Y.-F.; Hou, H.-J. Nitrogen and phosphorus leaching losses from paddy fields with different water and nitrogen managements. Paddy Water Environ. 2011, 9, 333-342. [CrossRef]

30. Gao, S.-K.; Yu, S.-E.; Shao, G.-C.; She, D.-L.; Wang, M.; Guo, R.; Cao, R.-Z.; Yan, S.-F.; Ding, J.-H. Effects of Controlled Irrigation and Drainage on Nitrogen and Phosphorus Concentrations in Paddy Water. J. Chem. 2016, 2016, 1-9. [CrossRef] 
31. Ji, X.; Zheng, S.; Shi, L.; Liao, Y. Effect of Fertilization on Nutrient Leaching Loss From Different Paddy Soils in Dongting Lake Area. Acta Pedol. Sin. 2008, 45, 663-671.

32. Zhao, X.; Xie, Y.X.; Xiong, Z.Q.; Yan, X.Y.; Xing, G.X.; Zhu, Z.L. Nitrogen fate and environmental consequence in paddy soil under rice-wheat rotation in the Taihu lake region, China. Plant Soil 2009, 319, 225-234. [CrossRef]

33. Chen, Z.; Wang, H.; Liu, X.; Zhao, X.; Lu, D.; Zhou, J.; Li, C. Changes in soil microbial community and organic carbon fractions under short-term straw return in a rice-wheat cropping system. Soil Tillage Res. 2017, 165, 121-127. [CrossRef]

34. Hu, N.; Wang, B.; Gu, Z.; Tao, B.; Zhang, Z.; Hu, S.; Zhu, L.; Meng, Y. Effects of different straw returning modes on greenhouse gas emissions and crop yields in a rice-wheat rotation system. Agric. Ecosyst. Environ. 2016, 223, 115-122. [CrossRef]

35. Yang, S.; Wang, Y.; Liu, R.; Xing, L.; Yang, Z. Improved crop yield and reduced nitrate nitrogen leaching with straw return in a rice-wheat rotation of Ningxia irrigation district. Sci. Rep. 2018, 8, 9458. [CrossRef]

36. Yang, S.; Xiao, Y.; Xu, J.; Liu, X. Effect of straw return on soil respiration and NEE of paddy fields under water-saving irrigation. PLoS ONE 2018, 13, e0204597. [CrossRef] [PubMed]

37. Lu, H.; Qi, X.; Guo, X.; Towa, J.; Zhen, B.; Qiao, D.; Wang, Z.; Yang, B.; Han, Y. Canopy Light Utilization and Yield of Rice under Rain-Catching and Controlled Irrigation. Water 2018, 10, 1340. [CrossRef]

38. Xiao, M.-H.; Yu, S.-E.; She, D.; Hu, X.-J.; Chu, L.-L. Nitrogen and phosphorus loss and optimal drainage time of paddy field under controlled drainage condition. Arab. J. Geosci. 2014, 8, 4411-4420. [CrossRef]

39. Djaman, K.; Mel, V.; Diop, L.; Sow, A.; El-Namaky, R.; Manneh, B.; Saito, K.; Futakuchi, K.; Irmak, S. Effects of Alternate Wetting and Drying Irrigation Regime and Nitrogen Fertilizer on Yield and Nitrogen Use Efficiency of Irrigated Rice in the Sahel. Water 2018, 10, 711. [CrossRef]

40. He, H.; Yang, R.; Jia, B.; Chen, L.; Fan, H.; Cui, J.; Yang, D.; Li, M.; Ma, F.-Y. Rice Photosynthetic Productivity and PSII Photochemistry under Nonflooded Irrigation. Sci. World J. 2014, 2014, 1-14. [CrossRef]

41. Nyamai, M.; Mati, B.; Home, P.; Odongo, B.; Wanjogu, R.; Thuranira, E. Improving land and water productivity in basin rice cultivation in Kenya through System of Rice Intensification (SRI). Agric. Eng. Int. CIGR J. 2012, 14, 1-9.

42. Xiao, M.; Li, Y.; Wang, J.; Hu, X.; Wang, L.; Miao, Z. Study on the Law of Nitrogen Transfer and Conversion and Use of Fertilizer Nitrogen in Paddy Fields under Water-Saving Irrigation Mode. Water 2019, 11, 218. [CrossRef]

43. Xu, B.; Shao, D.; Tan, X.; Yang, X.; Gu, W.; Li, H. Evaluation of soil water percolation under different irrigation practices, antecedent moisture and groundwater depths in paddy fields. Agric. Water Manag. 2017, 192, 149-158. [CrossRef]

44. Tian, Y.H.; Yin, B.; Yang, L.Z.; Yin, S.X.; Zhu, Z.L. Nitrogen Runoff and Leaching Losses During Rice-Wheat Rotations in Taihu Lake Region, China. Pedosphere 2007, 17, 445-456. [CrossRef]

45. Xie, M.X.; Zhang, Z.Y.; Zhang, P.C.; Chen, T.J. Nitrate Nitrogen Transport and Leaching From Sloping Farmland of Purple Soil: Experimental and Modelling Approaches. Fresenius Environ. Bull. 2018, 27, 1508-1521.

46. Shao, G.-C.; Wang, M.-H.; Yu, S.-E.; Liu, N.; Xiao, M.-H.; Yuan, M. Potential of controlled irrigation and drainage for reducing nitrogen emission from rice paddies in Southern China. J. Chem. 2015, 2015, 1-9. [CrossRef]

47. Peng, S.; He, Y.; Yang, S.; Xu, J. Effect of controlled irrigation and drainage on nitrogen leaching losses from paddy fields. Paddy Water Environ. 2014, 13, 303-312. [CrossRef]

48. Eagle, A.J.; Bird, J.A.; Horwath, W.R.; Linquist, B.A.; Brouder, S.M.; Hill, J.E.; van Kessel, C. Rice yield and nitrogen utilization efficiency under alternative straw management practices. Agron. J. 2000, 92, 1096-1103. [CrossRef]

49. Wang, J.; Wang, D.; Zhang, G.; Wang, Y.; Wang, C.; Teng, Y.; Christie, P. Nitrogen and phosphorus leaching losses from intensively managed paddy fields with straw retention. Agric. Water Manag. 2014, 141, 66-73. [CrossRef]

50. Katsura, K.; Okami, M.; Mizunuma, H.; Kato, Y. Radiation use efficiency, N accumulation and biomass production of high-yielding rice in aerobic culture. Field Crops Res. 2010, 117, 81-89. [CrossRef]

51. Yang, S.; Peng, S.; Xu, J.; He, Y.; Wang, Y. Effects of water saving irrigation and controlled release nitrogen fertilizer managements on nitrogen losses from paddy fields. Paddy Water Environ. 2015, 13, 71-80. [CrossRef] 
52. Yang, S.; Peng, S.; Xu, J.; Hou, H.; Gao, X. Nitrogen Loss from Paddy Field with Different Water and Nitrogen Managements in Taihu Lake Region of China. Commun. Soil Sci. Plant Anal. 2013, 44, 2393-2407. [CrossRef]

53. Wang, M.; Yu, S.; Shao, G.; Gao, S.; Wang, J.; Zhang, Y. Impact of Alternate Drought and Flooding Stress on Water Use, and Nitrogen and Phosphorus Losses in a Paddy Field. Pol. J. Environ. Stud. 2018, 27, 345-355. [CrossRef]

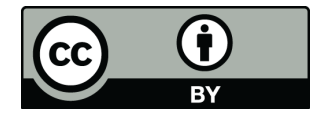

(C) 2019 by the authors. Licensee MDPI, Basel, Switzerland. This article is an open access article distributed under the terms and conditions of the Creative Commons Attribution (CC BY) license (http://creativecommons.org/licenses/by/4.0/). 